\title{
Sexual violence in armed conflicts: A violation of international humanitarian law and human rights law
}

\section{Gloria Gaggioli*}

Gloria Gaggioli has a $\mathrm{PhD}$ in International Law and is Assistant Professor/Grantholder of Excellence at the University of Geneva, Law Faculty, Department of Public International Law and International Organization.

\section{Abstract}

Sexual violence is prevalent in contemporary armed conflicts. International humanitarian law and human rights law absolutely prohibit all forms of sexual violence at all times and against anyone; international criminal law moreover provides for the individual criminal responsibility of sexual crimes' perpetrators. These three bodies of law importantly reinforce each other in this field. The discrepancy between the facts on the ground and the law is a matter of concern that cannot be explained by potential legal gaps or uncertainties. What is needed is to find new ways of improving implementation for existing laws at the domestic and international levels.

Keywords: rape, sexual violence, international humanitarian law, international human rights law, international criminal law, gender-based violence, conflict-related sexual violence, weapon, method of warfare, torture, cruel, inhuman or degrading treatments, crimes against humanity, acts of genocide, implementation, prosecution.

* Gloria Gaggioli was until recently Thematic Legal Adviser at the International Committee of the Red Cross (ICRC), where she dealt notably with the sexual violence file. However, this article was written in a purely personal capacity and does not necessarily reflect the views of the ICRC. The author would like to thank Iris Müller for her very useful comments on the first draft, as well as Maria Giovanna Pietropaolo for her thorough research and input for the section 'Sexual violence as a weapon or method of warfare'. 
Sexual violence has occurred during armed conflicts at all times, on all continents. It is still prevalent in a number of contemporary armed conflicts, such as in the Central African Republic, Colombia, Democratic Republic of the Congo (DRC), Mali, South Sudan and Syria. ${ }^{1}$ Some organizations ${ }^{2}$ and academics ${ }^{3}$ have provided figures that are alarming, but these data may show only the tip of the iceberg. One of the specific issues related to sexual violence is that it remains an "invisible" crime because feelings of guilt or shame, fear of retaliation or taboos may prevent victims from coming forward and talking about it. Material barriers such as security risks, physical distance and transportation costs may also prevent victims from seeking help. For humanitarian organizations that want to prevent sexual violence and respond to the needs of victims, this is a challenge. In its operational work, the International Committee of the Red Cross (ICRC) has therefore recently adopted a new approach. It presumes that sexual violence occurs in armed conflicts and endeavours to provide an appropriate humanitarian response to the victims of sexual violence even in the absence of allegations. ${ }^{4}$

Sexual violence, including when conflict-related, often has no relation to sexual desire, but is instead linked to power, dominance and abuse of authority. ${ }^{5}$ While women and girls are particularly vulnerable, men and boys are also victims of sexual violence, ${ }^{6}$ which may be committed by a variety of perpetrators: State actors, members of organized non-State armed groups, peacekeepers, members of private military and security companies, or simple individuals. Often, sexual violence is not perpetrated in isolation but accompanied by other violations, such

1 Peter Maurer, ICRC President Calls for Action on Sexual Violence in Conflict, statement of 12 June 2014, available at: www.icrc.org/eng/resources/documents/statement/2014/06-12-sexual-violence-statementmaurer.htm (all internet references were accessed in October 2014).

2 According to the United Nations (UN), over 200,000 women have suffered sexual violence in the DRC since the armed conflict began; between 250,000 and 500,000 women were raped during the 1994 genocide in Rwanda; and between 20,000 and 50,000 during the armed conflict in Bosnia in the early 1990s. See UN Resources for Speakers on Global Issues, "Ending Violence Against Women and Girls", available at: www.un.org/en/globalissues/briefingpapers/endviol/.

3 In 2014, researchers from Harvard Kennedy School, the Peace Research Institute Oslo and Yale University released a Sexual Violence in Armed Conflict Dataset which tracks reports of conflict-related sexual violence committed against civilians (men, women, boys and girls) by armed actors involved in armed conflict over a recent twenty-year period. They report conflict-related sexual violence in $57 \%$ of the individual conflicts analyzed, with $14 \%$ at the highest prevalence level. See Dara Kay Cohen and Ragnhild Nordås, Sexual Violence in Armed Conflict Dataset, 4 November 2014, available at: www. sexualviolencedata.org; Dara Kay Cohen and Ragnhild Nordås, "Sexual Violence in Armed Conflict: Introducing the SVAC Dataset, 1989-2009”, Journal of Peace Research, Vol. 51, No. 3, May 2014, p. 423.

4 See the Q\&A with ICRC President Peter Maurer in the issue of the Review. See also Pierre Krähenbühl, "Sexual Violence in Armed Conflicts: Addressing the Causes and the Consequences", interview, 19

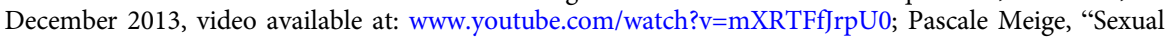
Violence in Armed Conflicts: An Invisible Tragedy", interview, 7 March 2014, video available at: www. icrc.org/eng/resources/documents/audiovisuals/video/2014/03-07-sexual-violence-pascale-meige.htm.

5 See, among many others, Dara Kay Cohen, Amelia Hoover Green and Elisabeth Jean Wood, "Wartime Sexual Violence: Misconceptions, Implications, and Ways Forward", Special Report of the United States Institute of Peace, No. 323, February 2013, p. 6, available at: www.usip.org/sites/default/files/wartime\% 20sexual\%20violence.pdf; Patrick Chiroro, Gerd Bohner, G. Tendayi Viki and Christopher Jarvis, "Rape Myth Acceptance and Rape Proclivity: Expected Dominance Versus Expected Arousal in Acquaintance-Rape Situations", Journal of Interpersonal Violence, Vol. 19, No. 4, 2004, pp. 427-442.

6 For a contribution challenging the assumption that women and girls are more vulnerable to rape and other forms of sexual violence, see the Opinion Note by Chris Dolan in this issue of the Review. 
as unlawful killings, child recruitment, destruction of property or looting. Its causes (direct and indirect) can be numerous, including the climate of impunity which is rampant in armed conflicts, the absence of clear orders/instructions prohibiting sexual violence, the proliferation of small arms and light weapons used to threaten victims, the increased vulnerabilities of victims of armed conflicts (internally displaced persons, migrants, widows, etc.), and the destruction of community ties and individual coping mechanisms. Sexual violence can also be used in a strategic or tactical way by parties to armed conflicts. In all cases, it has devastating consequences - primarily for the victims themselves, of course, because of its negative physical, psychological, social and economic effects, but also for the victims' relatives, who face possible trauma, feelings of indignity and guilt at having been unable to protect their next-of-kin. It may also have consequences for entire communities when it creates fear and destroys the social fabric. ${ }^{7}$

Despite its prevalence, sexual violence is not an unavoidable consequence of warfare and violence. Like any other violation, it can be prevented. A precondition for this is a strong legal framework and the existence of solid institutions to implement the prohibition of sexual violence. This article will demonstrate that sexual violence is absolutely and adequately prohibited under international law, and more precisely under international humanitarian law (IHL) and human rights law. Moreover, during the last twenty years, international criminal law has considerably evolved and has criminalized the most serious forms of sexual violence at the international level. These three bodies of international law strongly complement and positively influence each other in this field. This is not to say that sexual violence does not give rise to legal controversies, but rather that international law as it is even if not perfect - provides sufficient and adequate rules. The implementation of these rules at the national and international levels, however, needs to be strengthened to effectively eliminate or at least reduce the occurrence of sexual violence.

Before providing an overview of the international legal framework relating to sexual violence under IHL, human rights law and international criminal law, key terms such as sexual violence and rape will be defined. In the last section, the discrepancy between the law and the facts on the ground will be addressed and potential solutions presented.

\section{What are rape and sexual violence?}

\section{Defining sexual violence}

In the Akayesu case, the International Criminal Tribunal for Rwanda (ICTR) Trial Chamber held that sexual violence is "any act of a sexual nature which is committed

7 On the phenomenon of sexual violence, see ICRC, "Sexual Violence: Questions and Answers", 10 November 2013, available at: www.icrc.org/eng/resources/documents/faq/sexual-violence-questionsand-answers.htm. See also ICRC, "Engaging with Students and Professors on the Issue of Sexual Violence in Armed Conflicts: Workshop", 25 August 2014, available at: www.icrc.org/eng/resources/ documents/feature/2014/08-25-sexual-violence-worshop-tool.htm. 
on a person under circumstances which are coercive". 8 The term "act of a sexual nature" is very broad. It may range from penetration to comments having a sexual connotation. "Coercion" moreover must be understood broadly as including not only a show of physical force but also " $[\mathrm{t}]$ hreats, intimidation, extortion and other forms of duress which prey on fear or desperation". 9 The Trial Chamber further held that "sexual violence is not limited to a physical invasion of the human body and may include acts which do not involve penetration or even physical contact". ${ }^{10}$ From this definition, it is clear that sexual violence encompasses and is broader than rape. But is there a minimum threshold of gravity to consider an act as "sexual violence" when committed under coercive circumstances?

There is no clear-cut answer to this question. The Statute of the International Criminal Court (ICC) criminalizes "sexual slavery, enforced prostitution, forced pregnancy, enforced sterilization or any other form of sexual violence of comparable gravity" " ${ }^{11}$ This is a non-exhaustive list of the most serious forms of sexual violence falling under the jurisdiction of the ICC, which does not help to define the minimum gravity threshold for an act to be considered "sexual violence". Case law and legal writings nevertheless provide a number of additional concrete examples of sexual violence: for instance, trafficking for sexual exploitation, ${ }^{12}$ mutilation of sexual organs, ${ }^{13}$ sexual exploitation (such as obtaining sexual services in return for food or protection), ${ }^{14}$ forced abortions, ${ }^{15}$ enforced contraception, ${ }^{16}$ sexual assault, ${ }^{17}$ forced marriage, ${ }^{18}$ sexual harassment

8 ICTR, Prosecutor v. Jean-Paul Akayesu, Case No. ICTR-96-4, Judgment (Trial Chamber), 2 September 1998, para. 688; ICTR, Prosecutor v. Alfred Musema, Case No. ICTR-96-13, Judgment (Trial Chamber), 27 January 2000, para. 965.

9 Ibid.

10 ICTR, Akayesu, above note 8, para. 688.

11 Rome Statute of the International Criminal Court, 17 July 1998 (entered into force 1 July 2002), UN Doc. A/CONF.183/9 (Rome Statute), Arts 7(1)(g), 8(2)(b)(xxii), 8(2)(e)(vi) (emphasis added).

12 See Protocol to Prevent, Suppress and Punish Trafficking in Persons, Especially Women and Children, supplementing the United Nations Convention against Transnational Organized Crime, 15 November 2000, 2237 UNTS 319 (Protocol), Art. 3.

13 ICTR, Prosecutor v. Théoneste Bagosora, Case No. ICTR-96-7, Judgment (Trial Chamber), 18 December 2008, para. 976.

14 Megan Bastick, Karin Grimm and Rahel Kunz, Sexual Violence in Armed Conflict: Global Overview and Implications for the Security Sector, Geneva Centre for the Democratic Control of Armed Forces, 2007, p. 19. See also World Health Organization (WHO), World Report on Violence and Health, ed. Etienne G. Krug, 2002, p. 149 .

15 M. Bastick, K. Grimm and R. Kunz, above note 14, p. 19; WHO, above note 14, p. 149.

16 M. Bastick K. Grimm and R. Kunz, above note 14, p. 19.

17 See Geneva Convention (IV) relative to the Protection of Civilian Persons in Time of War, Geneva, 12 August 1949 (GC IV), Art. 27; Protocol Additional to the Geneva Conventions of 12 August 1949, and relating to the Protection of Victims of International Armed Conflicts, 8 June 1977 (AP I), Art. 75(2) (b); Protocol Additional to the Geneva Conventions of 12 August 1949, and relating to the Protection of Victims of Non-International Armed Conflicts, 8 June 1977 (AP II), Art. (4)(2)(e); Rome Statute, Art. 8(2)(e)(vi); Statute of the International Tribunal for Rwanda, 8 November 1994 (ICTR Statute), Art. 4(e); Statute of the Special Court for Sierra Leone, 16 January 2002 (SCSL Statute), Art. 3(e); and UN Transitional Administration in East Timor, Regulation No. 2000/15, Section 6.1(e)(vi).

18 M. Bastick K. Grimm and R. Kunz, above note 14, p. 49; WHO, above note 14, p. 149. 
(such as forced stripping), ${ }^{19}$ forced inspections for virginity ${ }^{20}$ and forced public nudity have been qualified as sexual violence. ${ }^{21}$

According to the World Health Organization (WHO), sexual violence can be defined as "any sexual act, attempt to obtain a sexual act, unwanted sexual comments or advances, or acts to traffic, or otherwise directed, against a person's sexuality using coercion, by any person regardless of their relationship to the victim, in any setting, including but not limited to home and work". ${ }^{22}$ If one accepts such a definition, then, it seems that the threshold of gravity is very low and that the term "violence" encompasses not only physical but also verbal or psychological violence. ${ }^{23}$

It should also be noted that if the ICC prosecutes only sexual violence of certain gravity, this does not mean that forms of sexual violence which may not reach that gravity cannot be considered an international crime under other treaties or national legislations. This is evidenced by the fact that, for instance, the Statute of the Special Court for Sierra Leone criminalizes - under crimes against humanity - "rape, sexual slavery, enforced prostitution, forced pregnancy and any other form of sexual violence". ${ }^{24}$

\section{Defining rape}

At the international level, rape has been essentially defined by the international criminal tribunals for Rwanda and the former Yugoslavia through three main cases. The first is the Akayesu case before the ICTR, in which the Trial Chamber (and then the Appeals Chamber) adopted a very broad and generic definition of rape. ${ }^{25}$ The ICTR simply held that rape is "a physical invasion of a sexual nature, committed on a person under circumstances which are coercive". 26

While the International Criminal Tribunal for the former Yugoslavia (ICTY) seemed initially to follow the approach taken by the ICTR, ${ }^{27}$ it shifted to a more precise definition of rape in the Furundžija case. ${ }^{28}$ Others would say that the ICTY did not radically depart from the ICTR definition but rather provided additional details on the constituent elements of acts considered to be rape. ${ }^{29}$ After having noted that it was not possible to draw the elements of rape from

19 ICTR, Akayesu (Trial Judgment), above note 8, para. 693.

20 M. Bastick K. Grimm and R. Kunz, above note 14, p. 19; WHO, above note 14, p. 150.

21 ICTR, Akayesu (Trial Judgment), above note 8, para. 688; ICTY, Prosecutor v. Dragoljub Kunarac and Others, Case No. IT-96-23\&23/1 (Trial Chamber), 22 February 2001, paras 766-774.

22 WHO, above note 14 , p. 149.

23 See also "Definitions of Sexual and Gender-based Violence", IRIN, available at: www.irinnews.org/ indepthmain.aspx? InDepthId=20\&ReportId=62847.

24 SCSL Statute, Art. 2 on "Crimes against Humanity".

25 ICTR, Akayesu (Trial Chamber), above note 8; see also Judgment (Appeals Chamber), 1 June 2001.

26 Ibid. (Trial Chamber), paras 596-598, 686-688. See also ICTR, Musema, above note 8, para. 965.

27 ICTY, Prosecutor v. Zejnil Delalić and Others (Celebici case), Case No. IT-96-21, Judgment (Trial Chamber), 16 November 1998.

28 ICTY, Prosecutor v. Anto Furundžija, Case No. IT-95-17-1, Judgment (Trial Chamber), 10 December 1998, para. 185.

29 ICTR, Prosecutor v. Mikaeli Muhimana, Case No. ICTR-95-1B, Judgment (Trial Chamber), 28 April 2005, paras 547-551. 
international treaty law or customary law, the ICTY Trial Chamber conducted a comparative law analysis in order to extrapolate the "common denominators" of rape in the criminal law of major legal systems. It concluded that the objective elements (actus reus) of rape are:

i) the sexual penetration, however slight: a) of the vagina or anus by the penis of the perpetrator or any other object used by the perpetrator, or b) of the mouth of the victim by the penis of the perpetrator; ii) by coercion or force or threat of force against the victim or third person". ${ }^{30}$

In the Kunarac case, the Trial Chamber considered that the Furundžija definition was too narrow. ${ }^{31}$ While it maintained part (i) of the definition, it went one step further by clarifying - or rather broadening - part (ii). For the Trial Chamber, an act of sexual penetration constitutes rape not only if accompanied by "coercion or force or threat of force against the victim or a third person" but also if there are other factors which would render the act "non-consensual or non-voluntary" on the part of the victim. The key criterion is therefore the lack of consent or voluntary participation. The Trial Chamber further held that "[i]n practice, the absence of genuine and freely given consent or voluntary participation may be evidenced by the presence of ... various factors ...- such as force, threats of force, or taking advantage of a person who is unable to resist". ${ }^{32}$ In other words, these factors are not elements of the crime of rape, but rather evidence of the lack of genuine consent. The Trial Chamber therefore "replaced" in the Kunarac case the second part of the Furundžija definition with "where such sexual penetration occurs without the consent of the victim". ${ }^{33}$

The ICC Elements of Crimes integrate these case-law evolutions and provide an even more refined definition of rape. An act is considered rape if:

1. The perpetrator invaded the body of a person by conduct resulting in penetration, however slight, of any part of the body of the victim or of the perpetrator with a sexual organ, or of the anal or genital opening of the victim with any object or any other part of the body. 2 . The invasion was committed by force, or by threat of force or coercion, such as that caused by fear of violence, duress, detention, psychological oppression or abuse of power, against such person or another person, or by taking advantage of a coercive environment, or the invasion was committed against a person incapable of giving genuine consent. ${ }^{34}$

30 ICTY, Furundžija (Trial Chamber), above note 28, para. 185.

31 ICTY, Kunarac (Trial Chamber), above note 21, para. 438.

32 Ibid., para. 458.

33 Ibid., para. 460. See also ICTY, Prosecutor v. Dragoljub Kunarac and Others, Case No. IT-96-23\&23/1 (Appeals Chamber), 12 June 2002, paras 125-133. In this case, the Appeals Chamber made clear that detention may substitute for non-consent.

34 See, e.g., ICC, Elements of Crimes, 2011, Art. 8(2)(b)(xxii)-1, available at: www.icc-cpi.int/NR/rdonlyres/ 336923D8-A6AD-40EC-AD7B-45BF9DE73D56/0/ElementsOfCrimesEng.pdf. 
The international community generally accepts this definition as the most authoritative. ${ }^{35} \mathrm{~A}$ number of national legislations have been adopted or modified to include the crime of rape and other sexual crimes as defined by the ICC. ${ }^{36}$

\section{Sexual violence versus gender-based violence}

In contradistinction with rape and sexual violence, there is no internationally agreed-upon definition of "gender-based violence". As a consequence, many different definitions of this term can be found.

The Committee on the Elimination of Discrimination against Women (CEDAW Committee) defined gender-based violence in its General Recommendation No. 19 in 1992 as "violence that is directed against a woman because she is a woman or that affects women disproportionately. It includes acts that inflict physical, mental or sexual harm or suffering, threats of such acts, coercion and other deprivations of liberty." ${ }^{37}$ While this definition is broad in terms of acts covered, it seems limitative regarding the persons covered. Genderbased violence is described as a form of discrimination ${ }^{38}$ against women exclusively. This restriction may be due to the mandate of the CEDAW Committee, or perhaps to the fact that, in practice, women and girls are (or at least are perceived as) the persons most affected by gender-based violence because of the subordinate status of women and girls vis-à-vis men and boys in a number of societies. Nowadays, the term "gender-based violence" is usually understood as covering not only women and girls but also men and boys. As noted by the Inter-Agency Standing Committee (IASC), ${ }^{39}$ although the term "gender-based violence" is often used interchangeably with the term "violence against women", men and boys may also be victims of gender-based violence especially sexual violence ${ }^{40}$ - based on socially determined roles, expectations and

35 For instance, WHO seems to rely on the ICC definition, although its working definition seems less precise and complete. See WHO, above note 14, p. 149: "Sexual violence includes rape, defined as physically forced or otherwise coerced penetration - even if slight - of the vulva or anus, using a penis, other body parts or an object."

36 See the national legislations of Australia, Belgium, Canada, Georgia, New Zealand, the Republic of Korea, South Africa and the United Kingdom mentioned in the Practice related to Rule 93 of Jean-Marie Henckaerts and Louise Doswald-Beck (eds), Customary International Humanitarian Law, Vol. 1: Rules, ICRC, Cambridge University Press, Cambridge, 2005 (ICRC Customary Law Study). See also, e.g., Philip Weiner, "The Evolving Jurisprudence of the Crime of Rape in International Criminal Law", Boston College Law Review, Vol. 54, No. 3, 2013, p. 1218. For instance, some organizations have reported that in the DRC a new law on rape and sexual violence has been adopted in 2007 and has been inspired by the ICC Statute. See Victim's Rights Working Group, The Impact of the Rome Statute System on Victims and Affected Communities, April 2010, p. 27, available at: www.vrwg.org/ VRWG_DOC/2010_Apr_VRWG_Impact_of_ICC_on_victims.pdf.

37 CEDAW Committee, General Recommendation No. 19, 1992, para. 6.

38 Ibid., para. 7.

39 On the IASC, see www.humanitarianinfo.org/iasc/pageloader.aspx?page=content-about-default.

40 IASC, Guidelines for Gender-Based Violence Interventions in Humanitarian Settings: Focusing on Prevention of and Response to Sexual Violence in Emergencies, September 2005, p. 4; See also UN Office for the Coordination of Humanitarian Affairs, "Gender-Based Violence", available at: www. irinnews.org/indepthmain.aspx?InDepthId=20\&ReportId=62847. 
behaviours linked to ideas about masculinity. Thus, the IASC provides for a broad and often-used - definition of gender-based violence as "an umbrella term for any harmful act that is perpetrated against a person's will, and that is based on socially ascribed (gender) differences between males and females". ${ }^{41}$ Similarly, the ICRC defines gender-based violence as an "overall term, including sexual violence and other types of gender-specific [violence that are] not necessarily sexually-based". ${ }^{2}$ In turn, the ICRC defines "gender" as

culturally expected behaviour of men and women based on roles, attitudes and values ascribed to them on the basis of their sex, whereas the term "sex" refers to biological and physical characteristics of a person. Gender roles vary widely within and between cultures, and depend on the particular social, economic and political context. ${ }^{43}$

Examples of gender-based violence include domestic violence, rape, sexual exploitation/abuse, forced prostitution, trafficking, forced/early marriage, female genital mutilation, honour killings and compulsory sterilization or abortion. ${ }^{44}$

From these definitions and examples, one can deduce first that genderbased violence is generally broader than sexual violence. Indeed, gender-based violence includes not only acts of sexual violence, such as rape, sexual mutilation (e.g. breast mutilations) and other forms of sexual abuse, but also acts of a non-sexual nature such as certain forms of domestic violence (e.g. battery) or honour killings (e.g. dowry deaths). Second, what distinguishes "gender-based violence" from any other form of violence is not the act in itself (e.g. killing, rape, battery, mutilation) but that it is "gender-specific". In other words, the violent act is committed "based on socially ascribed (gender) differences between males and females" or because of the gender of the victim. For instance, if a person has been murdered because he/she was transgender or homosexual, this is a gender-based crime. In this sense, sexual violence can be seen as sometimes broader than gender-based violence. A detainee may be raped in detention - as a method of torture - independently of his/her gender or socially ascribed role in society. The argument has sometimes been made, however, that sexual violence is always a form of gender-based violence because the links between sex and gender are too intricate to be distinguished. This is not the view of the author of this article-such an interpretation would conflate the meanings of sex and gender, which are different, as noted above.

41 IASC, above note 40. See also the definition of the European Institute for Gender Equality, available at: http://eige.europa.eu/content/what-is-gender-based-violence. For a critical assessment of the IASC 2005 Gender-Based Violence Guidelines, see the Opinion Note by Chris Dolan in this issue of the Review.

42 Charlotte Lindsey, Women Facing War Study, ICRC, Geneva, 2001, pp. 35-36.

43 See Charlotte Lindsey-Curtet et al., Addressing the Needs of Women Affected by Armed Conflict: An ICRC Guidance Document, ICRC, Geneva, 2004, p. 7; C. Lindsey, above note 42, p. 35.

44 IASC, above note 40; CEDAW Committee, above note 37; C. Lindsey, above note 42, pp. 35-36. 


\section{The prohibition of sexual violence under IHL}

\section{Does IHL overlook sexual violence?}

IHL treaties have sometimes been criticized because they allegedly do not take appropriately into account the needs of women in armed conflicts and because they do not prohibit and criminalize sexual violence in a sufficiently robust way. ${ }^{45}$ It is submitted that this criticism is excessively harsh. While the Geneva Conventions of 1949 and their Additional Protocols of 1977 may not be perfect in their approach to sexual violence, they provide the necessary protections from and prohibitions against rape and other forms of sexual violence. This is done in different ways: first, rape is expressly prohibited; and second, the prohibition of rape and other forms of sexual violence is encompassed in less explicit provisions such as the prohibitions against cruel treatment and torture, outrages upon personal dignity, indecent assault and enforced prostitution, and those intended to ensure respect for persons and honour.

Rape was already expressly prohibited in the famous Lieber Code of 1863. Its Article 44 provided that:

All wanton violence committed against persons in the invaded country ... all rape, wounding, maiming, or killing of such inhabitants, are prohibited under the penalty of death, or such other severe punishment as may seem adequate for the gravity of the offense. A soldier, officer or private, in the act of committing such violence, and disobeying a superior ordering him to abstain from it, may be lawfully killed on the spot by such superior. ${ }^{46}$

Interestingly, the sanction - death - was particularly severe.

Among early treaties regulating armed conflict, the Hague Regulations of 1899 and 1907 protect the "family honour and rights" of the population of an occupied territory. ${ }^{47}$ The 1929 Geneva Convention on prisoners of war provides that prisoners of war are entitled to respect for "their persons and honour" and that "women [prisoners of war] shall be treated with all consideration due to their sex". ${ }^{48}$ From an early stage, IHL treaties showed an awareness of sexual violence during armed conflict and aimed at preventing it, even though, as products of their time, they did not address it in express terms.

45 Judith Gardam, "Women, Human Rights and International Humanitarian Law", International Review of the Red Cross, No. 324, September 1998, pp. 421-432; Judith Gardam and Michelle Jarvis, Women, Armed Conflict and International Law, Kluwer Law International, The Hague, 2001. See also, on the criticisms made by these authors, Helen Durham, "Women, Armed Conflict and International Law", International Review of the Red Cross, Vol. 84, No. 847, 2002, pp. 655-659.

46 Lieber Code: Instructions for the Government of Armies of the United States in the Field, General Order No. 100, 24 April 1863, Art. 44, available at: www.icrc.org/ihl/INTRO/110.

47 Convention (II) with Respect to the Laws and Customs of War on Land and its Annex: Regulations Concerning the Laws and Customs of War on Land, The Hague, 1899, Art. 46; Convention (III) relative to the Opening of Hostilities, The Hague, 1907, Art. 46.

48 Convention relative to the Treatment of Prisoners of War, Geneva, 27 July 1929, Art. 3. 
In contemporary IHL treaties, rape and other forms of sexual violence are prohibited in both international and non-international armed conflicts. In international armed conflicts, the Third Geneva Convention of 1949 continues to provide that prisoners of war are "in all circumstances entitled to respect for their persons and honour" and that "women shall be treated with all regard due to their sex". ${ }^{49}$ The drafters used the same language as the 1929 Convention on prisoners of war. The Fourth Geneva Convention is more explicit and provides that civilian "women shall be especially protected against any attack on their honour, in particular against rape, enforced prostitution, or any form of indecent assault". ${ }^{50}$ While the Fourth Geneva Convention-adopted in 1949 as the first treaty specifically on the protection of the civilian population during armed conflict expressly addresses rape and other forms of sexual violence, this phrasing has been criticized because rape and sexual violence seem to be characterized as an intrusion on the victim's honour and thus as not reflecting the seriousness of the offence, i.e. an attack against the physical and psychological well-being of the victim. ${ }^{51}$ This wording indeed seems euphemistic and old-fashioned today, but the notion of "honour" had a completely different connotation at the time. While they seem weak and symbolic today, notions of honour (as evidenced by the principle of chivalry, for instance) were considered highly important constraints in war and were at the core of IHL rules in 1949 and before. ${ }^{52}$ In any case, and because of these fundamental changes of values and societal norms, the connection between sexual violence and honour is less present in more recent IHL treaties. ${ }^{53}$ Additional Protocol I to the Geneva Conventions (AP I), of 1977, provides that "outrages upon personal dignity, in particular humiliating and degrading treatment, enforced prostitution and any form of indecent assault", are "prohibited at any time and in any place whatsoever, whether committed by civilian or by military agents". 54 Two additional provisions protect specifically women "against rape, enforced prostitution and any other form of indecent assault" 55 and children "against any form of indecent assault". ${ }^{56}$

In non-international armed conflicts, Article 3 common to the four Geneva Conventions - which has been described by the International Court of Justice (ICJ) as reflecting "elementary considerations of humanity" applicable in all types of armed conflicts ${ }^{57}$-implicitly also prohibits sexual violence when it outlaws "violence to life and person, in particular ... mutilation, cruel treatment and

49 Geneva Convention (III) relative to the Treatment of Prisoners of War, 12 August 1949 (GC III), Art. 14.

50 GC IV, Art. 27.

51 J. Gardam, above note 45; C. Lindsey, above note 42, p. 57.

52 Terry D. Gill, "Chivalry: A Principle of the Law of Armed Conflict", in M. Matthee et al. (eds), Armed Conflict and International Law: In Search of the Human Face, TMC Asser Press, The Hague, 2013, pp. 33-51. See also Louise Doswald-Beck and Sylvain Vité, "International Humanitarian Law and Human Rights Law”, International Review of the Red Cross, No. 293, March-April 1993, pp. 94-119.

53 C. Lindsey-Curtet, above note 43, p. 12.

54 AP I, Art. 75(2)(b).

55 AP I, Art. 76(1)

56 AP I, Art. 77(1).

57 ICJ, Military and Paramilitary Activities in and against Nicaragua (Nicaragua v. United States of America), Judgment, ICJ Reports 1986, para. 218. See also ICJ, The Corfu Channel Case, Judgment, ICJ Reports 1949, p. 22 . 
torture" as well as "outrages upon personal dignity, in particular humiliating and degrading treatment". It is complemented by Additional Protocol II (AP II) of 1977, which, where/when applicable, prohibits, in the provision on fundamental guarantees, "outrages upon personal dignity, in particular humiliating and degrading treatment, rape, enforced prostitution and any form of indecent assault" for "all persons who do not take a direct part or who have ceased to take part in hostilities" (i.e. civilians and persons hors de combat). ${ }^{58}$ This is the first IHL provision explicitly prohibiting rape without distinction between women and men.

Customary IHL also prohibits rape and other forms of sexual violence. ${ }^{59}$ According to the ICRC Customary Law Study, this prohibition has been found to apply both in international and non-international armed conflicts and protects women, girls, boys and men. ${ }^{60}$ The Customary Law Study relied on a vast body of national and international practice - such as, in particular, military manuals, domestic legislations and national case law, international case law and United Nations (UN) resolutions - to reach this conclusion. ${ }^{61}$

\section{Which "conflict-related" sexual violence amounts to a violation of IHL?}

Sexual violence can be committed in peacetime, or during armed conflicts or other situations of violence. It can be committed by a variety of actors for a variety of purposes. Even when committed in times of armed conflict, sexual violence is not necessarily "conflict-related".

The term "conflict-related sexual violence" is not used in IHL treaties and is not properly legal. It is however increasingly used ${ }^{62}$ and sometimes understood as a synonym of sexual violence that amounts to an IHL violation. Various actors define "conflict-related sexual violence" differently. The UN, for instance, describes "conflict-related sexual violence" as

58 AP II, Art. 4(2)(e).

59 ICRC Customary Law Study, above note 36, Rule 93.

60 Ibid.

61 For the practice, see the Customary International Humanitarian Law Online Database, available at: www. icrc.org/customary-ihl/eng/docs/v1_rul_rule93.

62 See note 63 below. See also UN Women, Addressing Conflict-Related Sexual Violence: An Analytical Inventory of Peacekeeping Practice, June 2010, available at: www.unwomen.org/ /media/Headquarters/ Media/Publications/en/04DAnAnalyticalinventoryofPeacekeepingPracti.pdf; UN Department of Political Affairs, Guidance for Mediators: Addressing Conflict-Related Sexual Violence in Ceasefire and Peace Agreements, New York, 2012, available at: www.un.org/wcm/webdav/site/undpa/shared/undpa/pdf/DPA\% 20Guidance $\% 20$ for\%20Mediators\%20on\%20Addressing\%20Conflict-Related $\% 20$ Sexual\%20Violence $\% 20$ in \%20Ceasefire\%20and\%20Peace\%20Agreements.pdf; Sarah S. Shteir, Conflict Related Sexual and GenderBased violence: An Introductory Overview to Support Prevention and Response Efforts, Civil-Military Occasional Papers, Australian Civil-Military Centre, January 2014, available at: http://fr.slideshare.net/ CivMilCoE/occasional-paper-12014-conflictrelated-sexual-and-genderbased-violence; Organization for Security and Cooperation in Europe (OSCE), Combating Impunity for Conflict-Related Sexual Violence in Bosnia and Herzegovina: Progress and Challenges, Sarajevo, February 2014, available at: www.isn.ethz.ch/ Digital-Library/Publications/Detail/?lng=en\&id=179069. 
sexual violence, that ... occur[s] in conflict or post-conflict settings or other situations of concern (e.g. political strife) [and that] ... ha[s] a direct or indirect nexus with the conflict or political strife itself, that is, a temporal, geographical and/or causal link. In addition to the international character of the suspected crimes (which can, depending on the circumstances, constitute war crimes, crimes against humanity, acts of genocide or other gross violations of human rights), the link with conflict may be evident in the profile and motivations of the perpetrator(s), the profile of the victim(s), the climate of impunity/State collapse, cross-border dimensions and/or the fact that they violate the terms of a ceasefire agreement. ${ }^{63}$

If one accepts such a wide definition of "conflict-related sexual violence" - which is understandable from a humanitarian and operational perspective - it is clear that not all conflict-related sexual violence amounts to a violation of IHL and a war crime. ${ }^{64}$ IHL applies only in armed conflict situations and to acts that have a direct, or at least sufficient, link or nexus to an armed conflict. ${ }^{65}$

It is true that the notion of nexus cannot be found in IHL treaties and has been mainly developed in international criminal case law for the purpose of determining the jurisdiction of the tribunal or, in other words, establishing whether a war crime has been committed. ${ }^{66}$ It is submitted, however, that the requirement of a nexus to distinguish war crimes/other violations of IHL from ordinary crimes that may be committed during an armed conflict but that have no link with it exists both under IHL and international criminal law. In this specific context, the notion of nexus should be defined in a similar way under both international criminal law and IHL. ${ }^{67}$ Ultimately, to be considered a war crime, the applicability of IHL must be accepted since war crimes are serious

63 Conflict-Related Sexual Violence: Report of the Secretary-General, UN Doc. A/66/657-S/2012/33, 13 January 2012, para. 3; see also "Analytical and Conceptual Framing of Conflict-Related Sexual Violence", Stop Rape Now, available at: www.pakresponse.info/LinkClick.aspx?fileticket=QmSWiCA4rUw $\% 3$ D\&tabid $=71 \&$ mid $=433$.

64 It is to be noted that not all IHL violations constitute war crimes; war crimes are serious violations of IHL. See below section "Does Sexual Violence Always Amount to a Grave Breach and/or a War Crime?"

65 ICTY, Prosecutor v. Duško Tadić, Case No. IT-94-1-T, Judgment (Trial Chamber), 7 May 1997, para. 572; ICTY, Prosecutor v. Kordić and Čerkez, Case No. IT-95-14/2-T, Judgment (Trial Chamber), 26 February 2001, para. 32. It shall be noted that the ICTY, unlike the Preparatory Commission for the ICC, has apparently treated the nexus as being merely a jurisdictional requirement. See Knut Dörmann, Elements of War Crimes Under the Rome Statute of the International Criminal Court, Cambridge University Press, Cambridge, 2002, p. 27. In the same vein, the ICTR used the terminology of a "direct link", "direct connection" or "direct conjunction" with the armed conflict. Cf. ICTR, Akayesu (Trial Chamber), above note 8, para. 643; ICTR, Prosecutor v. Kayishema and Ruzindana, Case No ICTR-951-T, Judgment (Trial Chamber), 21 May 1999, paras 602-603, 623; ICTR, Musema (Trial Chamber), above note 8, para. 260; ICTR, Prosecutor v. Ntakirutimana, Case No. ICTR-96-10 and ICTR-96-17-T, Judgment (Trial Chamber), 21 February 2003, para. 861.

66 Ibid.

67 Under IHL, the notion of nexus is also used for instance in the context of the definition of the notion of direct participation in hostilities. See Nils Melzer, Interpretive Guidance on the Notion of Direct Participation in Hostilities under International Humanitarian Law, ICRC, Geneva, 2009, pp. 58-64. This context is however different because the notion of nexus is used to answer another question, i.e. "Does the act amount to direct participation in hostilities?", not "Is the act a violation of IHL?" 
violations of IHL. In order to clarify the notion of nexus in this context, the following example can be considered.

In the context of a non-international armed conflict, if a military commander rapes a subordinate soldier in a military barracks as a form of punishment - as he may have done already in peacetime - without this act having any link to the armed conflict situation, IHL would not apply to the act. This rape would/should however be prohibited under domestic law. It also constitutes a human rights violation if the military commander committed the rape in his official capacity (i.e. by using his position of authority and the means of his function). On the other hand, in the same armed conflict, if the military commander rapes a person detained for reasons connected to the armed conflict, such an act clearly constitutes a violation of IHL (and human rights law). The nexus derives from a number of elements here: the identity of the perpetrator (a military commander), the identity of the victim (a person detained for reasons related to the armed conflict), and the context (situation of vulnerability of detainees to the Detaining Power).

While these examples might seem obvious, the nexus with the armed conflict is not always so easy to determine. ${ }^{68}$ It is not because IHL is applicable at a given place and time that all acts occurring in this context are governed by IHL. The ICTY case law clarified moreover that for a nexus to exist, it is not necessary that substantial clashes be going on at the time and place in which the crimes were allegedly committed. ${ }^{69}$ It is sufficient that the alleged crimes were closely related to the hostilities occurring in other parts of the territories controlled by the parties to the conflict. ${ }^{70}$ It is not necessary either for the crime to be "part of a policy or practice officially endorsed or tolerated by one of the parties to the conflict, or that the act be in actual furtherance of a policy associated with the conduct of the war or in the actual interest of a party to the conflict". ${ }^{71}$ In the Kunarac case - which can safely be described as the reference case for defining the nexus requirement - the Appeals Chamber held that:

What ultimately distinguishes a war crime from a purely domestic offence is that a war crime is shaped by or dependent upon the environment - the armed conflict - in which it is committed. It need not have been planned or supported by some form of policy. The armed conflict need not have been causal to the commission of the crime, but the existence of an armed conflict must, at a minimum, have played a substantial part in the perpetrator's ability to commit it, his decision to commit it, the manner in which it was committed or the purpose for which it was committed. Hence, if it can be

68 For an article showing the difficulties in identifying the contours of the nexus and attempting to clarify (in a restrictive manner) the concept, see Harmen van der Wilt, "War Crimes and the Requirement of a Nexus with an Armed Conflict", Journal of International Criminal Justice, Vol. 10, No. 5, 2012, pp. 1113-1128.

69 Ibid. See also ICTY, Prosecutor v. Blaškić, Case No. IT-95-14, Judgment (Trial Chamber), 3 March 2000, para. 69; ICTY, Kunarac (Appeals Chamber), above note 33, para. 57.

70 Ibid.

71 ICTY, Blaškić (Trial Chamber), above note 69, paras 69 ff.; ICTY, Tadić (Trial Chamber), above note 65, para. 573. 
established, as in the present case, that the perpetrator acted in furtherance of or under the guise of the armed conflict, it would be sufficient to conclude that his acts were closely related to the armed conflict. ${ }^{72}$

The formula "under the guise of the armed conflict" has sometimes been criticized as overly broad..$^{73}$ The ICTR has however usefully explained that "the expression 'under the guise of the armed conflict' does not mean simply 'at the same time as an armed conflict' and/or 'in any circumstances created in part by the armed conflict" ${ }^{74}$ It gave the example of a non-combatant taking advantage of the lessened effectiveness of the police in conditions of disorder created by an armed conflict to murder a neighbour he had hated for years, and affirmed that this would not, without more, constitute a war crime. ${ }^{75}$ Contrariwise, the killings of civilian Tutsis by military officials and civilians alike were considered as having a nexus with the armed conflict taking place at the time between Rwandan government forces and the Rwandan Patriotic Front (RFP, an organized nonState armed group consisting of Tutsis), and thus as amounting to war crimes. The fact that the Tutsi ethnic minority was identified with the RFP, the participation of military officials in the killing and the fact that the identification of infiltrators from the RFP served as an alleged motive for the killings of Tutsis were considered as indicia for the nexus. ${ }^{76}$

In the Kunarac case, the Appeals Chamber also identified a number of factors to determine whether or not an alleged offence is sufficiently related to the armed conflict to constitute a war crime (and hence a violation of IHL). These factors included:

the fact that the perpetrator is a combatant; the fact that the victim is a noncombatant; the fact that the victim is a member of the opposing party; the fact that the act may be said to serve the ultimate goal of a military campaign; and that the crime is committed as part of or in the context of the perpetrator's official duties. ${ }^{77}$

These factors are not exhaustive; they are not cumulative either. For instance, not only combatants but also civilians can commit war crimes, and they can do so even if they have no special relationship with one party to the conflict. ${ }^{78}$ The Kunarac factors are provided simply as examples of what factors could be taken into account to determine the existence of a nexus. As evidenced by these

ICTY, Kunarac (Appeals Chamber), above note 33, para. 58.

H. van der Wilt, above note 68, p. 1125.

74 ICTR, Prosecutor v. Rutaganda, Case No. ICTR-96-3-A, Judgment (Appeals Chamber), 26 May 2003, para. 570.

75 Ibid.

76 ICTR, Prosecutor v. Semanza, Case No. ICTR-97-20-T, Judgment (Trial Chamber), 15 May 2003, paras $518 \mathrm{ff}$.

77 ICTY, Kunarac (Appeals Chamber), above note 33, para. 59.

78 ICTR, Akayesu (Trial Judgment), above note 8, para. 444. See also ICTY, Prosecutor v. Vasiljević, Case No. IT-98-32-T, Judgment (Trial Chamber), 29 November 2002, para. 57; and contra, H. van der Wilt, above note 68 , p. 1128. 
examples, the ad hoc tribunals have always used an "objective test" to determine the existence of a nexus; they did not require any mental element. ${ }^{79}$

Along the lines of the ad hoc tribunal case law, the ICC Elements of Crimes provide that for a war crime to exist, it must be committed "in the context of and associated with" an armed conflict. ${ }^{80}$ The wording "in the context of" refers to the existence of an armed conflict, and "associated with" refers to the nexus requirement. Conflict-related sexual violence must thus be committed by a person (whether combatant or civilian) in the context of and associated with an armed conflict in order to amount to a war crime under the Rome Statute. The Rome Statute formulation does not offer more precision compared to the case law of the international criminal tribunals for the former Yugoslavia and Rwanda. It is difficult, however, to define in abstracto precise criteria to determine the existence of a nexus that would offer an adequate response to all possible scenarios. Such a determination needs to be made on a case-by-case basis.

\section{Sexual violence as a weapon or method of warfare?}

Sexual violence in armed conflict, particularly rape, is sometimes qualified as a "weapon of war" and/or as a "method of war". ${ }^{81}$

Under IHL, a generally accepted definition of "weapon" does not exist, even though some attempts have been made to circumscribe the notion. A cursory analysis of different definitions adopted at the national and international levels reveals the existence of two common elements in the understanding of the notion: "weapon" refers to (i) an object, material, instrument, mechanism, device

79 K. Dörmann, above note 65, p. 27. See also Guénaël Mettraux, International Crimes and the Ad Hoc Tribunals, Oxford University Press, Oxford, 2005, p. 45.

80 See, for instance, Elements of Crimes, above note 34, Art. 8(2)(a)(i)-1.

81 For the UN, see, for instance, UNGA Res. 48/143 (1993); UN Doc. A/RES/48/143; Office of the High Commissioner for Human Rights, "Rape: Weapon of War", available at: www.ohchr.org/en/ newsevents/pages/rapeweaponwar.aspx; UNICEF, "Sexual Violence as a Weapon of War", available at: www.unicef.org/sowc96pk/sexviol.htm. For the media, see, for instance, Laura Smith-Spark, "How Did Rape Become a Weapon of War?", BBC News, undated, available at: http://news.bbc.co.uk/2/hi/ 4078677.stm; Kate McGuinness, "Rape as a Weapon of War", Huffington Post, 28 November 2012, available at: www.huffingtonpost.com/kate-mcguinness/rape-as-a-weapon-of-war_b_2202072.html; "Hague And Jolie Hail Anti-Rape Military Action”, Sky News, 28 March 2014, available at: http://news. sky.com/story/1233609/hague-and-jolie-hail-anti-rape-military-action. According to the latter article, UK Foreign Secretary William Hague said that "rape has unjustly been considered a 'lesser' crime, ... it has only recently been understood as a method of warfare". See also Global Justice Center, Rape as a Weapon of War, available at http://globaljusticecenter.net/index.php/our-work/geneva-initiative/rapeas-a-weapon-of-war; Janet Benshoof, The Other Red Line: Holding States Accountable for the Use of Rape as an Unlawful Weapon or Tactic of Warfare, excerpts on file with the author. The author writes: "Although strategic rape is condemned as a weapon of war, some IHL experts narrow that characterization by insisting that strategic rape is a 'tactic' or 'method' of war, without denoting what underlying weapons, such as the penis, are used to effectuate strategic rape. ... [I]n practice the term 'tactic' can have the practical effect of removing it from further scrutiny under the IHL weapons framework." For scholars, see for instance Anna Maedl, "Rape as a Weapon of War in the Eastern DRC? The Victims' Perspective", Human Rights Quarterly, Vol. 33, No. 1, 2011, pp. 128-147; Judith Gardam, "Women and the Law of Armed Conflict: Why the Silence?", International and Comparative Law Quarterly, Vol. 46, No. 1, 1997, p. 59: "rape in the conflict of the former Yugoslavia assumed the characteristic of a method of warfare". 
or substance that is used to (ii) kill, injure, damage, threaten or destroy. ${ }^{82}$ If such a definition is accepted, it is clear that the characterization of rape or other forms of sexual violence as a weapon of war is inaccurate from a strict IHL perspective. Instead, sexual violence is an unlawful and criminal behaviour. ${ }^{83}$

In contrast, a "method of warfare" is generally understood as the way in which a weapon is used, ${ }^{84}$ or as any specific tactical or strategic way of conducting hostilities that is intended to overwhelm and weaken the adversary. ${ }^{85}$ Sometimes, sexual violence is resorted to as a tactical or strategic way of overwhelming and weakening the adversary, either directly, or indirectly by hurting the civilian population perceived as supporting the enemy. This is particularly the case when it is carried out in a systematic manner and covered by the chain of command. It is in this sense that sexual violence may sometimes have been referred to as a "method of warfare". It is important to point out, however, that this characterization of rape or other sexual violence may create a confusion between the conduct of hostilities in the strict and technical sense of the term (and the - lawful or unlawful-methods used in that context), and the treatment of persons in the hands or power of the enemy. The lawfulness or unlawfulness of certain weapons or methods of warfare depends ultimately on their indiscriminate nature, and on whether they cause superfluous injury or unnecessary suffering or a combination thereof. ${ }^{86}$ Sexual violence, instead, is prohibited as such against anyone, irrespective of status. In practice, sexual violence can only be committed against persons who are under the control of the perpetrator. Any type of violence - such as sexual violence-committed against persons in the hands or power of the enemy is absolutely prohibited by IHL rules on the treatment of persons. Sexual violence is, by definition, unnecessary or "superfluous" as the person against whom it is committed is already hors de combat. Reference to the prohibition of superfluous injury or unnecessary suffering in this context would therefore be redundant and might even be

82 ICRC, A Guide to the Legal Review of New Weapons, Means and Methods of Warfare: Measures to Implement Article 36 of Additional Protocol I of 1977, ICRC, Geneva, 2006, p. 9, fn. 17. This guide provides several national definitions of weapons. See also Program on Humanitarian Policy and Conflict Research, Harvard University, Manual on International Law Applicable to Air and Missile Warfare, 2009, p. 6: a weapon is "a means of warfare used in combat operations, including a gun, missile, bomb or other munitions, that is capable of causing either (i) injury to, or death of, persons; (ii) damage to, or destruction of, objects". See also the definition proposed in the Weapons Law Encyclopedia by the Geneva Academy of International Humanitarian Law and Human Rights: "A weapon is a device that is construed, adapted or used to kill, injure, disorient, or threaten a person or to inflict damage on a physical object. A weapon may act through kinetic energy or by other means, such as transmission of electricity, diffusion of chemical substances or biological agents or sound, or direction of electromagnetic energy".

83 At best, the appellative of "weapon" could be attributed to the bodily fluid of an HIV-positive person. The latter had been defined "deadly weapon" (alongside the penis) by a US National Court. See Court of Appeals of Texas, Jose Fonseca Najera v. The State of Texas, Case No. 03-96-00189-CR, 1997.

84 Yves Sandoz, Christophe Swinarski and Bruno Zimmermann (eds), Commentary on the Additional Protocols, ICRC, Geneva, 1987, on AP I, Art. 51, para. 1957.

85 Marco Sassòli, Antoine Bouvier and Anne Quintin, How Does Law Protect in War?, ICRC, Geneva, 2011, p. 280.

86 See the 1907 Hague Regulations, Art. 23(e); AP I, Arts 35(2), 51(4)(b) and (c). For the customary nature of these rules, see ICRC Customary Law Study, above note 36, Rules 70 and 71. 
considered erroneous as it relates to the conduct of hostilities (in the technical sense of the term) and not to the absolute protection of persons in the hands or power of the enemy against inhuman treatment. Characterizing rape or other forms of sexual violence as a method of warfare thus does not add to the absolute prohibition of such acts under IHL.

The characterizations of rape as a "weapon of war" or a "method of warfare" are nowadays very common, but these terms are usually resorted to in a non-technical way ${ }^{87}$ to attach a particular stigma to the crime of rape ${ }^{88}$ and to indicate that rape is not just a by-product of war - that it is not just committed opportunistically or randomly, but may be part of a strategy. ${ }^{89}$ In order to keep that important connotation and stigmatization while avoiding confusion with IHL rules and principles on the conduct of hostilities, it may therefore be more accurate to characterize sexual violence as an unlawful policy, tactic or strategy during armed conflict.

\section{The prohibition of sexual violence under human rights law}

Human rights law applies at all times. ${ }^{90}$ It is thus necessary to briefly analyze human rights rules that might possibly prohibit sexual violence and thus complement IHL in times of armed conflict (in particular regarding acts of sexual violence that have no nexus with the armed conflict), as well as to provide useful guidance on the interpretation and application of IHL prohibitions against sexual violence.

\section{The lack of specific prohibitions against sexual violence in most human rights treaties}

Surprisingly, most human rights treaties, universal and regional, do not contain explicit or specific prohibitions of sexual violence. ${ }^{91}$ Even the Convention on the

87 See, for example, the recurring mention of rape as a "weapon of war" in UNGA Res. 48/143 (1993), UN Doc. A/RES/48/143. The resolution states, for example, that "this heinous practice [rape and abuse of women] constitutes a deliberate weapon of war in fulfilling the policy of "ethnic cleansing". The resolution therefore defines a practice in terms of "weapon" even though the notion of weapons usually only encompasses objects, substances and materials, and not practices.

88 See, for instance, Global Justice Centre, Fact-Sheet: Stopping the Use of Rape as a Tactic of War: A New Approach, June 2014, available at: http://globaljusticecenter.net/index.php?option= com_mtree\&task=att_download\&link_id=412\&cf_id=34: "Embedding strategic rape within the purview of the laws of war governing the legality of tactics and weapons will foster its stigmatization, which has proven critical to stopping the use of other abhorrent weapons and tactics."

89 In this sense, see L. Smith-Spark, above note 81.

90 ICJ, Legality of the Threat or Use of Nuclear Weapons, Advisory Opinion, ICJ Reports 1996, para. 25; ICJ, Legal Consequences of the Construction of a Wall in the Occupied Palestinian Territory, Advisory Opinion, ICJ Reports 2004, para. 106; ICJ, Armed Activities on the Territory of the Congo (Democratic Republic of the Congo v. Uganda), ICJ Reports 2005, paras 216-217. There is, however, a minority view according to which human rights law does not apply to armed conflicts. See ICJ, Legality of the Threat or Use of Nuclear Weapons, Advisory Opinion, ICJ Reports 1996, para. 24.

91 See, for instance, the International Covenant on Civil and Political Rights (ICCPR), 1966; European Convention on Human Rights (ECHR), 1950; American Convention on Human Rights (ACHR), 1969; African Charter on Human and Peoples' Rights, 1981. 
Elimination of Discrimination against Women (CEDAW) of 1979 does not contain any provision to that effect. Only "traffic in women and exploitation of prostitution of women" is explicitly prohibited. ${ }^{92}$ IHL treaties - and even the 1949 Geneva Conventions - appear thus to be more explicit, specific and precise than human rights treaties in general as regards the prohibition of sexual violence.

There are rare exceptions. For instance, at the universal level, the Convention on the Rights of the Child of 1989 provides that States Parties must protect children from all forms of sexual exploitation and sexual abuse, including through the adoption of appropriate legislative, administrative, social and educational measures. ${ }^{93}$ States Parties must also prevent particularly: “(a) The inducement or coercion of a child to engage in any unlawful sexual activity; (b) The exploitative use of children in prostitution or other unlawful sexual practices; (c) The exploitative use of children in pornographic performances and materials." ${ }^{4}$ The State thus has an obligation to prevent and protect children from being sexually abused not only by State actors, but also by private actors (due diligence obligation).

At the regional level, the Inter-American Convention on the Prevention, Punishment and Eradication of Violence against Women of 1994 prohibits "violence against women", which includes not only physical and psychological but also sexual violence, whether it is committed in the public or private sphere. ${ }^{95}$ This Convention drew its inspiration from the non-binding United Nations Declaration on the Elimination of Violence against Women of 1993, which contains similar provisions. The Protocol to the African Charter on Human and Peoples' Rights of Women in Africa (Maputo Protocol) of 2003 prohibits violence against women in a similar way and contains a number of provisions aimed at protecting women from sexual violence. ${ }^{96}$ One provision deals specifically with armed conflicts and provides that:

States Parties undertake to protect asylum seeking women, refugees, returnees and internally displaced persons, against all forms of violence, rape and other forms of sexual exploitation, and to ensure that such acts are considered war crimes, genocide and/or crimes against humanity and that their perpetrators are brought to justice before a competent criminal jurisdiction. ${ }^{97}$

In the European system, there is no particular treaty on sexual violence or on the protection of women. In 2002, however, the Council of Europe adopted a recommendation on violence against women which defines violence against women as including rape and other forms of sexual violence and which notably

92 Convention on the Elimination of Discrimination against Women (CEDAW), 1979, Art. 6.

93 Convention on the Rights of the Child, 1989, Arts 19(1) and 34.

94 Ibid., Art. 34.

95 Inter-American Convention on the Prevention, Punishment and Eradication of Violence against Women, 1994, Arts 1-3.

96 See Protocol to the African Charter on Human and Peoples' Rights of Women in Africa, 2003 (Maputo Protocol), Arts 3(4), 4(2), 11(3), 12(1)(c)(d), 13(c), 14(2)(c), 22(b), 23(b).

97 Ibid., Art. 11(3). 
recommends that Member States "penalise rape, sexual slavery, forced pregnancy, enforced sterilisation or any other form of sexual violence of comparable gravity as an intolerable violation of human rights, as crimes against humanity and, when committed in the context of an armed conflict, as war crimes". ${ }^{98}$

Although not treaties, there are a number of other non-binding human rights documents that refer to the issue of sexual violence. The Beijing Declaration and Platform for Action, adopted at the Fourth World Conference on Women, deserves a special mention as it identified already in 1995 the themes of "violence against women" and "women and armed conflict" as critical areas of concern requiring urgent action, and highlighted that "acts of violence against women include violation of the human rights of women in situations of armed conflict, in particular ... systematic rape, sexual slavery and forced pregnancy". ${ }^{99}$

\section{Sexual violence as torture or cruel, inhuman or degrading treatment or punishment}

The fact that most human rights treaties do not contain a specific prohibition against sexual violence does not mean that they do not prohibit rape and other forms of sexual violence. The non-derogable (even jus cogens ${ }^{100}$ ) prohibition of torture or cruel, inhuman or degrading treatment or punishment contained in all general human rights treaties ${ }^{101}$ provides a strong basis to prohibit virtually all forms of sexual violence at all times.

Torture is defined in the UN Convention against Torture (CAT) as

any act by which severe pain or suffering, whether physical or mental, is intentionally inflicted on a person for such purposes as obtaining from him or a third person information or a confession, punishing him for an act he or a third person has committed or is suspected of having committed, or intimidating or coercing him or a third person, or for any reason based on discrimination of any kind, when such pain or suffering is inflicted by or at the instigation of or with the consent or acquiescence of a public official or other person acting in an official capacity. ${ }^{102}$

98 Council of Europe, Recommendation Rec(2002)5 of the Committee of Ministers to Member States on the Protection of Women against Violence, adopted by the Committee of Ministers on 30 April 2002 at the 794th meeting of the Ministers' Deputies, available at: https://wcd.coe.int/ViewDoc.jsp?id=280915.

99 Beijing Declaration and Platform for Action, adopted at the Fourth World Conference on Women, 1995, paras 112-130 on "Violence against Women" and paras 131-149 on "Women and Armed Conflict", available at: www.un.org/womenwatch/daw/beijing/pdf/BDPfA\%20E.pdf.

100 See, e.g., Report of the Special Rapporteur on Torture and Other Cruel, Inhuman or Degrading Treatment or Punishment, Juan E. Méndez, UN Doc. A/HRC/25/60, 10 April 2014, para. 40: “The prohibition against torture and other cruel, inhuman or degrading treatment or punishment enjoys the enhanced status of a jus cogens or peremptory norm of general international law."

101 See ICCPR, Art. 7; ECHR, Art. 3; etc.

102 UN Convention against Torture (CAT), 1984, Art. 1. See also the definition of torture in the InterAmerican Convention to Prevent and Punish Torture, 1985, which provides similar conditions. 
Rape can be presumed as always causing "severe pain or suffering". ${ }^{103}$ It is moreover always "intentionally inflicted". It may have a specific purpose such as obtaining information and probably always has the purpose of coercing the victim. This latter coercive element can be seen as inherent in armed conflict situations. ${ }^{104}$ Lastly, the CAT requires that torture be committed with the more or less direct involvement of a public official. This is not to say, however, that torture by a private individual does not raise human rights questions. States have a duty to protect individuals from torture by private individuals. ${ }^{105}$ Moreover, the European Court of Human Rights has considered that the prohibition against deporting a person to a third State where he/she may be tortured exists even if a non-State actor poses the threat of torture (provided that "the authorities of the receiving State are not able to obviate the risk by providing appropriate protection"). ${ }^{106}$

The Special Rapporteur against Torture had already noted in 1986 that sexual abuse is one of the various methods of physical torture. ${ }^{107}$ The case law of human rights bodies provides a number of concrete examples where sexual violence has been considered as amounting to torture or cruel, inhuman or degrading treatment or punishment. In particular, rape has often been considered as torture. For instance, in a case taking place in the context of Peru, the InterAmerican Commission on Human Rights (IACHR) considered that the rape by a Peruvian soldier of a woman who was suspected of belonging to a subversive group and whose husband had been abducted by the Peruvian army amounted to torture in the sense of the Inter-American Convention to Prevent and Punish Torture because it was committed intentionally by a State official with the purpose of punishing her personally and intimidating her. ${ }^{108}$ It is interesting to note that the IACHR relied inter alia on IHL to support its argument that

103 In the Kunarac case, the Appeals Chamber held that "sexual violence [not rape] necessarily gives rise to severe pain or suffering, whether physical or mental, and in this way justifies its characterisation as an act of torture". ICTY, Kunarac (Appeals Chamber), above note 33, para. 150.

104 ICTY, Delalić (Trial Chamber), above note 27, para. 495: "Rape causes severe pain and suffering, both physical and psychological. The psychological suffering of persons upon whom rape is inflicted may be exacerbated by social and cultural conditions and can be particularly acute and long lasting. Furthermore, it is difficult to envisage circumstances in which rape, by, or at the instigation of a public official, or with the consent or acquiescence of an official, could be considered as occurring for a purpose that does not, in some way, involve punishment, coercion, discrimination or intimidation. In the view of this Trial Chamber this is inherent in situations of armed conflict." See also ICTY, Prosecutor v. Brdanin, Case No. IT-99-36, Judgment (Trial Chamber), 1 September 2004, para. 485; ICTY, Prosecutor v. Stanisic and Zupljanin, Case No. IT-08-91-T, Judgment (Trial Chamber), 27 March 2013, para. 48; ICTY, Kunarac (Appeals Chamber), above note 33, para. 151; ICTR, Akayesu (Trial Judgment), above note 8, para. 682.

105 See, e.g., Human Rights Committee (HRC), General Comment 20/44: Prohibition of Torture, 3 April 1992, para 2.

106 See European Court of Human Rights (ECtHR), HLR v. France, Application No. 24573/94, Judgment, 29 April 1997, para 40.

107 Report of the Special Rapporteur on Torture, UN Doc. E/CN.4/1986/15, 19 February 1986, para. 119.

108 IACHR, Raquel Martín de Mejía v. Peru, Case No. 10.970, Report No. 5/96, Annual Report 1995, OEA/Ser. L/V/II.91 Doc. 7 rev. (1996), p. 185. 
[c] urrent international law establishes that sexual abuse committed by members of security forces, whether as a result of a deliberate practice promoted by the State or as a result of failure by the State to prevent the occurrence of this crime, constitutes a violation of the victims' human rights, especially the right to physical and mental integrity. ${ }^{109}$

The European Court of Human Rights (ECtHR) reached a similar conclusion, notably in the Aydin v. Turkey case of 1997 that concerned the rape of a 17-yearold girl detained by security forces on the basis of suspicion of collaboration by herself or members of her family with members of the PKK. The Court noted that the rape (together with other ill-treatments: the applicant was blindfolded, beaten, stripped and placed inside a tyre and sprayed with high-pressure water), which served the purpose of obtaining information, amounted to torture. ${ }^{10}$ The case law of the international criminal tribunals for the former Yugoslavia and Rwanda confirms that rape amounts to torture. ${ }^{111}$

Not only rape but also other forms of sexual abuse can amount to torture or cruel, inhuman or degrading treatment or punishment. For instance, the IACHR considered that forcing someone to witness the rape of close relatives constitutes "a form of humiliation and degradation that is a violation of the right to humane treatment". ${ }^{112}$ The Committee against Torture held that imposing involuntary sterilization is a cruel treatment. ${ }^{113}$ The ECtHR described the strip-searching of a male prisoner in the presence of a female prison officer as a degrading treatment. ${ }^{114}$ The ICTY held that sexual assaults (including ramming a police truncheon in the anus of a detainee or forcing male prisoners to perform oral sex on each other, sometimes in front of other prisoners) amounted to torture. ${ }^{115}$ The prohibition against using sexual violence of any kind as an official punishment is also clearly established. ${ }^{116}$ This list is far from exhaustive.

Lastly, it shall be noted that the United Nations Convention against Torture and Other Cruel, Inhuman or Degrading Treatment or Punishment explicitly

109 Ibid.

110 ECtHR, Aydin v. Turkey, Application No. 57/1996/676/866, Judgment, 25 September 1997, paras 83-86. The Court noted: "Rape of a detainee by an official of the State must be considered to be an especially grave and abhorrent form of ill-treatment given the ease with which the offender can exploit the vulnerability and weakened resistance of his victim. Furthermore, rape leaves deep psychological scars on the victim which do not respond to the passage of time as quickly as other forms of physical and mental violence. The applicant also experienced the acute physical pain of forced penetration, which must have left her feeling debased and violated both physically and emotionally. ... [T] he Court is satisfied that the accumulation of acts of physical and mental violence inflicted on the applicant and the especially cruel act of rape to which she was subjected amounted to torture in breach of Article 3 of the Convention. Indeed the Court would have reached this conclusion on either of these grounds taken separately."

111 See notes 103 and 104 above.

112 IACHR, Ana, Beatriz and Celia González Pérez v. Mexico, Case No. 11.565, Report No. 53/01, Annual Report 2000, OEA/Ser.L/V/II.111 Doc. 20 rev. p. 1097 (2001), para. 53.

113 Committee against Torture, "Concluding Observations, Peru”, UN Doc. CAT/C/PER/CO/4, 25 July 2006, para. 23.

114 ECtHR, Valasinas v. Lithuania, Application No. 44558/98, Judgment, 24 July 2001.

115 ICTY, Prosecutor v. Simić, Tadić and Zarić, Case No IT-95-9, Judgment (Trial Chamber), 17 October 2003, paras 728 and 772 .

116 CEDAW Committee, above note 37, para. 8. See also ICRC Customary Law Study, above note 36, Rule 93. 
imposes a duty to proceed to a prompt and impartial investigation wherever there are reasonable grounds to believe that an act of torture has been committed.117 Although general human rights treaties do not contain a similar provision, human rights case law has clarified that, by virtue of the fundamental nature of the prohibition of torture or cruel, inhuman or degrading treatment or punishment, the mere fact that a State has not effectively investigated allegations of such violations, and has not prosecuted - and eventually punished ${ }^{118}$ - the perpetrators, may give rise to a separate violation of the prohibition against torture or other ill-treatment under its procedural limb and/or of the right to an effective remedy. ${ }^{119}$

\section{The interpretive value of human rights treaties for $\mathrm{IHL}$ as regards sexual violence}

The definition of torture, cruel, inhuman or degrading treatment or punishment under human rights law, and the numerous examples of human rights case law dealing with rape and other forms of sexual violence as a form of torture and other ill-treatments, are useful not only when interpreting these concepts under human rights law, but also when doing so under IHL and international criminal law. In the Kunarac case, for instance, the Trial Chamber of the ICTY highlighted that IHL does not contain any definition of torture. ${ }^{120}$ It thus referred to human rights law to define "torture" under both Articles 3 (violation of the laws and customs of war) and 5 (crime against humanity) of the ICTY Statute. Importantly, the Trial Chamber highlighted that:

Because of the paucity of precedent in the field of international humanitarian law, the Tribunal has, on many occasions, had recourse to instruments and practices developed in the field of human rights law. Because of their resemblance, in terms of goals, values and terminology, such recourse is generally a welcome and needed assistance to determine the content of customary international law in the field of humanitarian law. ${ }^{121}$

This does not mean, however, that the exact same definition applies under these different bodies of law: a certain amount of translation or transposition is necessary. The specificity of each body of law must be kept in mind. ${ }^{122}$ In particular, the ICTY Trial Chamber had to determine whether the criterion of the

117 CAT, Art. 12.

118 As highlighted in Rule 93 of the ICRC Customary Law Study, above note 36, there is an increased recognition of the need to punish all persons responsible for sexual violence. See, e.g., UNGA Res. 48/ 104 proclaiming the UN Declaration on the Elimination of Violence against Women, Art. 4(c); CEDAW Committee, above note 37, para. 9.

119 ECtHR, Aydin, above note 110, para. 103 (under Art. 13 of ECHR); ECtHR, M.C. v. Bulgaria, Application No. 39272/98, Judgment, 4 December 2003 (under Arts 3 and 13 of ECHR), paras 169-187; IACHR, Mejía v. Peru, above note 108 (under the violation of Arts 1(1), 8(1) and 25 of ACHR).

120 ICTY, Kunarac (Trial Chamber), above note 21, paras 465-497.

121 Ibid., para. 467.

122 Ibid., para. 470. 
involvement of a public official belongs to customary international law for the purpose of IHL and of Article 3 of the ICTY Statute. The Trial Chamber concluded that while this criterion is required under human rights law, it is not required under IHL because of the crucial structural differences as regards the role and position of the State as an actor in these two bodies of international law. ${ }^{123}$ In brief, even if the definition of torture - and of rape as torture or other inhuman or degrading treatment - is not exactly the same under human rights law, IHL and international criminal law, it is clear that the definitions provided under human rights law are of highly important interpretive value.

\section{Sexual violence as other human rights violations?}

Sexual violence can also be encompassed into other human rights violations depending on the circumstances. For instance, sexual slavery is included in the broader prohibition of slavery. ${ }^{124}$ There are a number of human rights treaties and instruments that require States to prevent, suppress and punish the trafficking of persons for the purpose of prostitution of others or other forms of sexual exploitation. ${ }^{125}$ The ECtHR and IACHR have also considered that sexual violence violates the right to privacy or to a private life. ${ }^{126}$ Lastly, gender-based violence-which includes, in many instances, sexual violence-constitutes discrimination. ${ }^{127}$

Here again, human rights practice and case law can constitute very useful tools of interpretation when it comes to concepts such as slavery or discrimination that can also be found under IHL and international criminal law. Human rights law also complements IHL by providing for additional rights/ prohibitions such as the prohibition of human trafficking or the right to privacy or to a private life that have no real equivalent under IHL.

123 IHL applies to all parties to an armed conflict, while human rights law binds de jure only States.

124 See, e.g., ECtHR, Rantsev v. Cyprus and Russia, Application no. 25965/04, Judgment, 7 January 2010, paras 272-309.

125 See, e.g., CEDAW, Art. 6. For human rights treaties on trafficking especially, see Convention for the Suppression of the Traffic in Persons and of the Exploitation of the Prostitution of Others, approved by UNGA Res. 317(IV) of 2 December 1949; Protocol to Prevent, Suppress and Punish Trafficking in Persons, Especially Women and Children, supplementing the UN Convention against Transnational Organized Crime, adopted by UNGA Res. 55/25, 15 November 2000; South Asian Association for Regional Cooperation, Convention on Preventing and Combating Trafficking in Women and Children for Prostitution, 2002. See also the following non-binding instruments: UN High Commissioner for Human Rights, Recommended Principles and Guidelines on Human Rights and Human Trafficking, text presented to the Economic and Social Council as an addendum to the report of the United Nations High Commissioner for Human Rights, UN Doc. E/2002/68/Add.1, 2002; ECOWAS, Declaration on the Fight against Trafficking in Persons; OAS Inter-American Commission of Women, Res. CIM/RES 225 (XXXI-0/02); "Human Rights Standards for the Treatment of Trafficked Persons", developed by the Human Rights Caucus of the International Human Rights Group and a number of NGOs and distributed by the Office for Democratic Institutions and Human Rights of the OSCE, January 1999.

126 See, for instance, IACHR, Mejía v. Peru, above note 108; ECtHR, X and Yv. The Netherlands, Application No. 8978/80, Judgment, 26 March 1985.

127 CEDAW Committee, above note 37. 


\section{Sexual violence as an international crime}

\section{Does sexual violence always amount to a grave breach of $\mathrm{IHL}$ and/or a war crime?}

For international armed conflicts, the Geneva Conventions of 1949 and AP I of 1977 criminalize certain serious violations of IHL through the specific system of grave breaches. ${ }^{128}$ They provide that each High Contracting Party is under an obligation to enact necessary legislation to provide effective penal sanctions for suspected offenders, to search them regardless of their nationality and of the place of the offence, and either prosecute them or extradite them to another High Contracting Party for trial. ${ }^{129}$ Requiring each High Contracting Party to bring alleged perpetrators, "regardless of their nationality, before its own courts", the grave breaches system underlines that these parties must try not only their own nationals but also foreign nationals alleged to have committed a grave breach. This latter obligation, to prosecute where nationality of the alleged offender as a traditional basis for jurisdiction is not given (and where, without this being explicitly stated, also other traditional jurisdictional bases such as nationality of the victim or territoriality jurisdiction may not be given), marks the principle of universal jurisdiction as one of the important features of the grave breaches system.

The list of grave breaches under the Geneva Conventions and AP I is rather short and does not explicitly contain rape or other forms of sexual violence. ${ }^{130}$ Some authors have analyzed this lack of express reference as an indication that States at the time did not consider rape and other forms of sexual violence as belonging to the most horrendous crimes that required specific criminalization. ${ }^{131}$ One can only speculate as to whether that was true in 1949 or even in 1977, but it is a matter of fact that rape and other forms of sexual violence were rarely prosecuted also at the international level before the emergence of the ad hoc international criminal tribunals for the former Yugoslavia and Rwanda in the 1990s. ${ }^{132}$

Today, it is clear that rape and other forms of sexual violence do amount to grave breaches if committed against protected persons in the context of and associated with an international armed conflict, when these acts fall into the categories of "torture or inhuman treatment" or "wilfully causing great suffering or serious injury to body or health". In the ICRC Customary IHL Study, the Commentary to Rule 156 ("Definition of War Crimes") explains that:

128 Convention (I) for the Amelioration of the Condition of the Wounded and Sick in Armed Forces in the Field, Geneva, 12 August 1949 (GC I), Arts 49-50; Convention (II) for the Amelioration of the Condition of Wounded, Sick and Shipwrecked Members of Armed Forces at Sea, Geneva, 12 August 1949 (GC II), Arts 50-51; GC III, Arts 129-130; GC IV, Arts 146-147; AP I, Arts 11, 85-86.

129 GC I, Art. 49; GC II, Art. 50; GC III, Art. 129; GC IV, Art. 146.

130 GC I, Art. 50; GC II, Art. 51; GC III, Art. 130; GC IV, Art. 147; AP I, Arts 11, 85-86.

131 See, for example, J. Gardam, above note 45.

132 See C. Lindsey, above note 42, p. 19. For some rare examples, For some rare examples, see W. Awochi Case, in UN War Crimes Commission, Law Reports of Trials of War Criminals, Vol. 13, 1949, p. 125 (on enforced prostitution); and Hoess Trial, in UN War Crimes Commission, Law Reports of Trials of War Criminals, Vol. 7, 1948, p. 15 (on enforced sterilization). 
Although rape was prohibited by the Geneva Conventions, it was not explicitly listed as a grave breach either in the Conventions or in Additional Protocol I but would have to be considered a grave breach on the basis that it amounts to inhuman treatment or wilfully causing great suffering or serious injury to body or health. ${ }^{133}$

The participants in the International Conference for the Protection of War Victims, held in Geneva from 30 August to 1 September 1993, went as far as declaring that "acts of sexual violence directed notably against women and children ... constitute grave breaches of international humanitarian law". ${ }^{134}$ The case law of international criminal tribunals has demonstrated that rape, notably, amounts to torture ${ }^{135}$ and, as such, can be prosecuted under the grave breaches provisions. For instance, in the Delalic case, some of the accused - in charge of the sadly famous Celebici camp were convicted for rape as torture under Article 2 of the ICTY Statute (grave breaches). ${ }^{136}$ Other serious forms of sexual violence have also been prosecuted under the grave breaches provisions; for instance, in Prlić, the ICTY Trial Chamber held that inhuman treatment under Article 2(b) of the ICTY Statute (grave breaches) can consist of "any sexual violence inflicted on the physical and moral integrity of a person by means of threat, intimidation or force, in such as a way $[s i c]$ as to degrade or humiliate the victim". ${ }^{137}$ More generally, rape and other forms of sexual violence can also be qualified as war crimes in the context of international armed conflicts, without necessarily being grave breaches. This is important to note in particular for sexual abuses that do not enter into the specific categories of grave breaches or that are committed against individuals who do not fall within the category of protected persons.

Under the lead of the United Kingdom, in the context of its Preventing Sexual Violence in Conflict Initiative (PSVI), ${ }^{138}$ States made two declarations in 2013 recalling that "rape and other forms of serious sexual violence in armed conflict are war crimes and constitute grave breaches of the Geneva Conventions and their first Protocol" (emphasis added). ${ }^{139}$ It is unclear whether these declarations aim at adding a new category into the list of grave breaches or whether they simply recall that rape and other forms of sexual violence amount to grave breaches when they enter into the already existing categories of "torture

133 ICRC Customary Law Study, above note 36, Rule 156.

134 Final Declaration of the International Conference for the Protection of War Victims, para. I.3, reprinted in International Review of the Red Cross, No. 296, September-October 1993, p. 377.

135 See above discussion and in particular above notes 103 and 104.

136 ICTY, Delalić (Trial Chamber), above note 27.

137 Emphasis added. ICTY, Prosecutor v. Prlić, Case IT-04-74-T, Judgment (Trial Judgment), 29 May 2013, para. 116.

138 On the UK PSVI, see www.stabilisationunit.gov.uk/how-to-get-involved/preventing-sexual-violenceinitiative.html.

139 The first Declaration was adopted by the G8 in April 2013. Available at: www.gov.uk/government/ publications/g8-declaration-on-preventing-sexual-violence-in-conflict. The second was adopted during the UN General Assembly Ministerial Week in September 2013 and has now been endorsed by more than 140 countries, available at: www.gov.uk/government/uploads/system/uploads/attachment_data/file/ 244849/A_DECLARATION_OF_COMMITMENT_TO_END_SEXUAL_VIOLENCE_IN_CONFLICT_ TO_PRINT....pdf. 
or inhuman treatment" or "wilfully causing great suffering or serious injury to body or health" and are committed against protected persons during international armed conflicts. The use of the verb "recall" in the declarations tends to imply the latter, and a representative of the UK has confirmed this interpretation. ${ }^{140}$ Moreover, the adjective "serious" added before sexual violence tends to indicate that not all forms of sexual violence would necessarily amount to a grave breach and a war crime generally. Since the lower threshold for an act to be qualified as sexual violence remains unclear, as discussed above, ${ }^{141}$ it is submitted that everything depends on the definition of "sexual violence" adopted. If sexual violence is understood as including, for instance, unwanted sexual comments or advances as suggested by the WHO, ${ }^{142}$ then it is probable that such an act would be considered as falling below the threshold of gravity of grave breaches of the Geneva Conventions and AP I, and of war crimes more generally.

With respect to non-international armed conflicts, surprising as it may be today, neither common Article 3 of the Geneva Conventions nor AP II of 1977 provide for the criminalization or prosecution of violations of IHL regulating non-international armed conflicts. As made clear in the Tadic case, however, serious violations of common Article 3 also constitute war crimes. ${ }^{143}$ Rape and other forms of sexual violence are implicitly or explicitly prohibited in common Article 3, as well as in AP II. ${ }^{144}$ To the extent that rape and other forms of sexual violence amount to a serious violation of these provisions, there is no doubt that they also amount to war crimes when committed in non-international armed conflicts. In the ICTY Statute, rape and other forms of sexual violence are not mentioned among the crimes that can be prosecuted when committed in a noninternational armed conflict, i.e. in Article 3 on violations of the laws or customs of war. This did not impede the ICTY, however, from considering rape and other forms of sexual violence as constituting war crimes in non-international armed conflicts. As is well known, Article 3 of the ICTY Statute has been interpreted as a residual clause covering any serious violation of IHL not covered by other articles of the Statute. ${ }^{145}$ The conditions for determining which violations fall within Article 3 of the ICTY were elaborated in the Tadic case (i.e. the famous four "Tadić conditions"). ${ }^{146}$ On this basis, in the Kunarac case, for instance, the three accused were charged with and found guilty notably of violations of the laws and customs of war in the form of rape and torture and outrages upon personal dignity (for other forms of sexual violence) in the context of the

140 Theo Rycroft, "Criminalization and Prosecution of Sexual Violence in Armed Conflict at the Domestic Level: Grave Breaches and Universal Jurisdiction", Proceedings of the Bruges Colloquium: Vulnerabilities in Armed Conflicts-Selected Issues, 14th Bruges Colloquium, 17-18 October 2013, College of Europe/ICRC, 2014, pp. 77, 79.

141 See above section "Defining Sexual Violence".

142 Above note 22.

143 ICTY, Prosecutor v. Tadić, Case No. IT-94-1-AR72, Decision (Appeals Chamber), 2 October 1995, paras $71 \mathrm{ff}$.

144 See above section "The Prohibition of Sexual Violence under IHL".

145 ICTY, Tadić (Appeals Chamber), above note 143, paras 89, 91.

146 Ibid., para. 94. 
non-international armed conflict in Bosnia and Herzegovina between 1992 and 1993. ${ }^{147}$ This case related to the systematic rape committed against Muslim women and girls mainly in private houses and apartments by members of the Bosnian Serb Army and of a Serb unit in the Foca area, which was being ethnically cleansed. In the ICTR Statute, Article 4 (violations of common Article 3 and AP II) explicitly criminalizes rape, enforced prostitution and any form of indecent assault. In the Musema case, for instance, the accused, the director of a tea factory, was charged notably with rape under Article 4 of the ICTR for having raped a Tutsi woman and encouraged his employees to do so in the context of the non-international armed conflict in Rwanda. ${ }^{148}$

Moreover, rape and other forms of sexual violence have now been explicitly recognized by States as a stand-alone category of war crimes (i.e. as grave breaches or serious violations of common Article 3 independent of a qualification as torture or inhuman treatment, wilfully causing great suffering or serious injury to body or health etc.) in both international and non-international armed conflicts. The Rome Statute, adopted by States in 1998, provides that "rape, sexual slavery, enforced prostitution, forced pregnancy, ... enforced sterilization, or any other form of sexual violence also constituting a grave breach of the Geneva Conventions" or a "serious violation of article 3 common" are war crimes in respectively international and non-international armed conflicts. ${ }^{149}$ This list implies that a certain threshold of gravity must be reached, but it is open-ended, thus leaving some room for jurisprudential interpretations. ${ }^{150}$ The wording "any other form of sexual violence also constituting a grave breach" for international armed conflicts, and "any other form of sexual violence also constituting a serious violation of article 3 common" for non-international armed conflicts, is not entirely clear. Does it mean that "other forms of sexual violence" must already constitute a grave breach/serious violation of common Article 3 to be criminalized under Articles $8(2)(\mathrm{b})(\mathrm{xxii})$ or $8(2)(\mathrm{e})(\mathrm{vi})$ of the ICC Statute? If the answer to this question were positive, the added value (effet utile) of this provision would be rather thin. The ICC Elements of Crimes tend to indicate that what actually matters is that "the conduct was of a gravity comparable to that of a grave breach" or "to that of a serious violation of article 3 common to the four Geneva Conventions". ${ }^{151}$ Acts of sexual violence not reaching this threshold of gravity

147 ICTY, Kunarac (Trial Chamber), above note 21; see also the Appeals Chamber Judgment of 12 June 2002. For another case before the ICTY concerning the crime of rape as a violation of the laws or customs of war, see ICTY, Prosecutor v. Kvočka et al., Case No IT-98-30/1 (Trial Chamber), 2 November 2001; see also the Appeals Chamber Judgment of 28 February 2005.

$148 \mathrm{He}$ was, however, not found guilty under that count, as the prosecutor had failed to establish the nexus with the armed conflict. See ICTR, Musema (Trial Chamber), above note 8. See also ICTR, Bagosora (Trial Chamber), above note 13.

149 See Rome Statute, Art. 8(2)(b)(xxii), which applies to international armed conflicts, and Art. 8(2)(e)(vi), which applies to non-international armed conflicts "that take place in the territory of a State when there is protracted armed conflict between governmental authorities and organized armed groups or between such groups" (see Art. 8(2)(f)).

150 See, in this sense, K. Dörmann, above note 65, p. 332.

151 See Elements of Crimes, above note 34. 
might still constitute an international crime, for instance as "outrages upon personal dignity, in particular humiliating and degrading treatment" in international armed conflicts as per Article 8(2)(b)(xxi) of the Rome Statute.

National case law recognizing that rape and other forms of sexual violence amount to war crimes when committed in the context of and associated with an armed conflict - whether international or non-international - is numerous today and tends to indicate that this is now part of customary law. ${ }^{152}$

\section{Can sexual violence amount to a crime against humanity and/or an act of genocide?}

In armed conflict situations, not only war crimes can be committed but also crimes against humanity and acts of genocide. It is therefore necessary to analyze whether rape and other forms of sexual violence can give rise to crimes against humanity and acts of genocide. If the answer is positive, this means that even acts of sexual violence that are not directly linked to the armed conflict can constitute international crimes.

The post-Second World War Control Council Law No. 10 was the first international legal instrument that expressly included rape in the list of crimes against humanity. ${ }^{153}$ It was followed by the ICTR Statute, ${ }^{154}$ the ICTY Statute ${ }^{155}$ and the ICC Statute. ${ }^{156}$ The latter added to the list as sexual acts constituting crimes against humanity: "sexual slavery, enforced prostitution, forced pregnancy, enforced sterilization, or any other form of sexual violence of comparable gravity" (along the lines of the list of sexual crimes as war crimes ${ }^{157}$ ). To amount to a crime against humanity, sexual crimes must however be committed as "part of a widespread or systematic attack directed against any civilian population, with knowledge of the attack". In other words, there must be a policy or a practice of committing crimes that are tolerated or condoned by a government or de facto authority. An isolated rape will be difficult to portray as a crime against humanity. The Kunarac case can be cited as a case in point in which rape and other forms of sexual violence amounted to a crime against humanity. ${ }^{158}$ The accused-members of either the Bosnian Serb Army or of Serb forces-were convicted for crimes against humanity in the form of rape, torture and enslavement because they took Muslim women and girls on a regular basis, raped

152 China, War Crimes Military Tribunal of the Ministry of National Defence, Takashi Sakai case, Judgment, 29 August 1946; Germany, Federal Prosecutor General, Charges against Two Alleged Leading Officials of the "Democratic Forces for the Liberation of Rwanda" (FDLR), press release, 17 December 2010; United States, Court of Military Appeals, John Schultz case, Judgment, 5 August 1952; United States, District Court of Columbia, Comfort Women case, Memorandum Opinion and Judgment, 4 October 2001. For more cases, see the Practice related to Rule 93 of the ICRC Customary Law Study.

153 Control Council Law No. 10, available at: http://avalon.law.yale.edu/imt/imt10.asp.

154 ICTR Statute, Art. 3(g).

155 ICTY Statute, Art. 5(g).

156 Rome Statute, Art. 7 (1)(g).

157 See above section "Does Sexual Violence Always Amount to a Grave Breach and/or a War Crime?"

158 ICTY, Kunarac, above notes 21 and 33. 
them and kept them in servitude in the context and furtherance of the ethnic cleansing of the Foca area. ${ }^{159}$

Sexual violence can even amount to an act of genocide when committed with intent to destroy, in whole or in part, a national, ethnical, racial or religious group, as such. ${ }^{160}$ Rape and other forms of sexual violence can fall into different categories of acts of genocide, in particular "causing serious bodily or mental harm to members of the group", "deliberately inflicting on the group conditions of life calculated to bring about its physical destruction in whole or in part" or "imposing measures intended to prevent births within the group". ${ }^{161}$ The most famous case in which sexual crimes were considered as acts of genocide is the Akayesu case. ${ }^{162}$ Jean-Paul Akayesu, bourgmestre of Taba commune in Rwanda from April 1993 to June 1994, was convicted for crimes against humanity and for acts of genocide, notably because he knew that members of the Interahamwe had systematically committed rapes and other forms of sexual violence against Tutsi girls and women, he took no measures to prevent or to punish the perpetrators, and he ordered, instigated and aided and abetted sexual violence. ${ }^{163}$ The Trial Chamber highlighted:

With regard, particularly, to ... rape and sexual violence, the Chamber wishes to underscore the fact that in its opinion, they constitute genocide in the same way as any other act as long as they were committed with the specific intent to destroy, in whole or in part, a particular group, targeted as such. Indeed, rape and sexual violence certainly constitute infliction of serious bodily and mental harm on the victims and are even, according to the Chamber, one of the worst ways of inflict[ing] harm on the victim as he or she suffers both bodily and mental harm. In light of all the evidence before it, the Chamber is satisfied that the acts of rape and sexual violence described above, were committed solely against Tutsi women, many of whom were subjected to the worst public humiliation, mutilated, and raped several times, often in public, in the Bureau Communal premises or in other public places, and often by more than one assailant. These rapes resulted in physical and psychological destruction of Tutsi women, their families and their communities. Sexual violence was an integral part of the process of destruction, specifically targeting Tutsi women and specifically contributing to their destruction and to the destruction of the Tutsi group as a whole. The rape of Tutsi women was systematic and was perpetrated against all Tutsi women and solely against them. ${ }^{164}$

Rape and other forms of sexual violence can thus also amount to genocide.

159 Ibid. See, in particular, Trial Judgment, above note 21, paras 436-464.

160 ICTR Statute, Art. 2; ICTY Statute, Art. 4; Rome Statute, Art. 6. See also Convention on the Prevention and Punishment of the Crime of Genocide, 9 December 1948.

161 Rome Statute, Arts 6(1)(b)(c) and (d).

162 ICTR, Akayesu (Trial Judgment), above note 8.

163 Ibid., paras $449-452$.

$164 \mathrm{Ibid}$., paras 731-732. 


\title{
The discrepancy between the law and the facts
}

\author{
No gap under international law
}

Rape and other forms of sexual violence are not only violations of human rights law and IHL entailing State responsibility; as discussed above, they can also amount to international crimes and, as such, entail individual criminal responsibility.

The prohibition of rape and other forms of sexual violence is one of the areas where IHL, human rights law and international criminal law go in the same direction, complementing and reinforcing each other. It is fascinating to see how frequently human rights bodies and the international criminal tribunals cite each other in order to reinforce their analysis in the field of sexual violence. For instance, in the Delalic case, the ICTY cited the ECtHR and the IACHR among other human rights bodies in order to conclude that rape amounts to torture. ${ }^{165}$ In the Pérez v. Mexico case, the IACHR notably cited the ICTY and the ECtHR for the same purpose. ${ }^{166}$ The latter, for instance, referred to the ICTY findings in the context of the M.C. v. Bulgaria case dealing with the alleged rape of a 14year-old girl by two men, to reject force as a necessary element of rape and to conclude that any sexual penetration without the victim's consent constitutes rape. ${ }^{167}$ This phenomenon of exchange between the various branches of international law has been called "cross-fertilization" by certain authors. ${ }^{168}$

On this basis, and as demonstrated in the previous sections, it can safely be said that the prohibition and criminalization of rape and other forms of sexual violence at the international level is strong and fairly adequate. This is not to say that international law is perfect in this regard. Some legal uncertainties always remain: for instance, is there a lower threshold for an act to amount to sexual violence? When does sexual violence committed during an armed conflict amount to a war crime? What is the lower threshold of gravity for sexual violence to constitute a serious violation of IHL? Should the notion of rape as torture be interpreted in the same way under human rights law, IHL and international criminal law? ${ }^{169}$ These grey areas have a rather limited impact in practice, however.

One may think that even though State practice and international case law have clarified a number of issues, it would still be useful to have a new binding treaty assembling these evolutions and/or integrating IHL, human rights and international

165 ICTY, Delalić (Trial Chamber), above note 27, paras 480-493.

166 IACHR, González Pérez v. Mexico, above note 112, paras 45-48.

167 EctHR, M.C. v. Bulgaria, above note 119, para. 163.

168 Gloria Gaggioli, L'influence mutuelle entre les droits de l'homme et le droit international humanitaire à la lumière du droit à la vie, Pedone, Paris, 2013, p. 196 (which contains references to other authors mentioning this "cross-fertilization"). See also Gloria Gaggioli, "The Relevance of International Criminal Law for Interpreting and Applying Human Rights Treaties: A Study of the Case Law of the European Court of Human Rights", in Robert Kolb and Damien Scalia, Droit international pénal, Helbing Lichtenhahn, Basel, 2012, pp. 397-422; Olivier de Frouville, "The Influence of the European Court of Human Rights' Case Law on International Criminal Law of Torture and Inhuman and Degrading Treatment", Journal of International Criminal Justice, Vol. 9, No. 3, 2011, pp. 633-649.

169 On this issue, see G. Gaggioli, “The Relevance of International Criminal Law”, above note 168. 
criminal law rules pertaining to sexual violence. Given the already existing strong international legal framework, the lack of appetite among States for new treaties nowadays and the inherent risk that every treaty-making exercise entails (i.e. opening for negotiation points which were solved through case law and other practice, thus jeopardizing the existing legal framework), it is unlikely that such an enterprise would bring more benefits than costs.

That being said, there is a shocking discrepancy between the prohibition and criminalization under international law of rape and other forms of sexual violence and the prevalence on the ground of such crimes in situations of armed conflict. It is submitted, however, that this discrepancy cannot be explained by the existence of a gap or lack of clarity in international law. What is urgently needed are not more international law rules but rather a better implementation of existing rules at the domestic level and effective prosecutions of perpetrators of sexual crimes at the domestic and international levels.

\section{Need for better implementation and prosecution}

International law rules prohibiting and criminalizing sexual violence remain dead letters if they are not properly implemented at the national level. This means first that international law rules must be integrated into domestic law. The domestic legal framework must prohibit and criminalize sexual violence in an adequate manner, in conformity with international rules and standards. Police and military orders, doctrines, rules of engagement etc. must also be in conformity with the international and domestic prohibition/criminalization of sexual violence. But even this-i.e. a strong domestic legal and administrative framework-is not sufficient.

These rules, to be effective, must be supported by robust State institutions. The security sector (i.e. the police, the military and other security forces) needs to be staffed and trained appropriately. Police and armed forces must put in place appropriate procedures so that disciplinary and criminal sanctions to prevent and punish sexual violence by State officials can be applied. They must also be trained to be able to recognize sexual violence when it happens and to protect the population from such crimes by non-state actors. The justice system needs to be staffed and trained appropriately in order to be able to investigate allegations of sexual violations and prosecute and sanction perpetrators. In many countries, rape and other forms of sexual violence are prohibited and criminalized, but the prosecutions for such crimes are virtually non-existent. The reasons for this might be numerous and varied. Sometimes the lack of referral systems for victims of sexual violence or the prospect of excessively long procedures explains why victims do not seek justice. At other times, it is the lack of trust in the State institutions that discourages victims of sexual violence from seeking justice. There might also be a lack of willingness on the part of the judicial system to prosecute sexual crimes, which are wrongly considered lesser crimes. Finally, a strong health system - with staff specially trained to recognize sexual violence and to provide the necessary assistance to victims - is also needed. Victims of sexual 
violence usually turn first to the health system for assistance; the role of medical personnel is therefore paramount to identifying sexual violence and to referring victims to the appropriate police and judicial authorities if the patient so wishes. In this context, notably, respect for medical ethics and confidentiality is absolutely essential. Assistance to victims of sexual violence is not limited to medical assistance. Economic assistance might also be needed: victims of sexual violence might lack a means of livelihood because, for instance, they have been rejected by their families and communities. Psychosocial support to the victims, but also their families and entire communities, is often required, in particular when sexual violence is committed on a large scale. Assistance to victims indirectly prevents sexual violence from occurring again as it helps reduce the vulnerability of the concerned persons and communities. Eliminating and preventing sexual violence might thus require profound reforms. ${ }^{170}$ These measures can and should already be taken in peacetime and are even more needed in armed conflicts and post-conflict settings.

In the context of armed conflicts, organized non-State armed groups also play an important role in the prevention of sexual violence. They too must enforce norms against rape and other forms of sexual violence by their members and by civilians in the territory they control. ${ }^{171}$ Although armed groups usually do not have "institutions" like States and cannot "prosecute" rape and other forms of sexual violence, they can take effective measures to prevent sexual violence: the existence of clear orders prohibiting any form of sexual violence, the appropriate training of members of the armed group, and the enforcement of disciplinary measures and sanctions against perpetrators are basic measures that can truly help to eliminate and prevent sexual violence.

The need to improve the implementation of IHL in the field of sexual violence was highlighted at the 31st International Conference of the Red Cross and Red Crescent in 2011, in the Four-Year Action Plan for the Implementation of IHL, which integrated as an objective the "[p]revention of sexual and other gender-based violence against women". The Action Plan provides that:

States ensure that all feasible measures are employed to prevent all serious violations of international humanitarian law involving sexual and other forms of gender-based violence against women. Such measures include: predeployment and in-theatre gender training of armed forces on their responsibilities, as well as the rights and particular needs and protection of women and girls; military disciplinary measures and other measures such as reporting requirements on incidents of sexual violence to avoid impunity; ensuring that female detainees and internees are supervised by women and

170 As noted by J. Gardam already in 1998, "to be effective, any enforcement regime for prohibitions on sexual violence in armed conflicts must incorporate procedural reforms”. J. Gardam, above note 45.

171 "Indeed, where groups enforce norms against rape by civilians (including spousal rape) as well as by combatants, the frequency of rape during war may be significantly less than peacetime levels." Elisabeth Jean Wood, "Armed Groups and Sexual Violence: When is Wartime Rape Rare?", Politics and Society, Vol. 37, No. 1, 2009, pp. 131-161. 
separated from male detainees and internees, except where families are accommodated as family units; ensuring, whenever possible, that female personnel are present during the interrogation of female detainees; and ensuring, whenever possible, women's participation in decision-making in peace processes. ${ }^{172}$

Since then, the ICRC has made a number of statements before UN bodies notably affirming the urgent need to improve the implementation of IHL and other international rules prohibiting and criminalizing sexual violence. ${ }^{173}$ It has already been suggested that the theme of sexual violence be put on the agenda of the 32nd International Conference of the Red Cross and Red Crescent that will take place in December 2015. ${ }^{174}$

The UN has also stressed the need to address the immediate and profound causes of sexual violence, notably in the thematic resolutions of the UN Security Council on the Protection of Civilians in Armed Conflict, on Women, Peace and Security, and on Children and Armed Conflicts. In these resolutions, the Security Council has linked the issue of sexual violence to the peace and security agenda. ${ }^{175}$ The Security Council took concrete actions and even applied sanctions against individuals for complicity in widespread and systematic sexual violence perpetrated in the DRC. ${ }^{176}$ The UN has also linked the issue of sexual violence with the "transitional justice" agenda, ${ }^{177}$ thus showing the UN belief that broad "institutional reforms are necessary to prevent the repetition of gender-based and sexual violence". ${ }^{178}$ These evolutions aim at improving the implementation of the prohibition of sexual violence at the international level.

Despite these positive developments, the need for better implementation and prosecution of sexual violence also exists at the international level. The lack

172 ICRC, 31st International Conference 2011: Resolution 2-4-Year Action Plan, 2011, available at: www.icrc. org/eng/resources/documents/resolution/31-international-conference-resolution-2-2011.htm.

173 See, e.g., UN General Assembly, 69th session, Third Committee, item 27 of the agenda, statement by the ICRC, New York, 17 October 2014, available at: www.icrc.org/en/document/advancement-women-icrcstatement-united-nations-2014\#.VHeG8BzP87k; UN General Assembly, 69th session, Third Committee, item 64 of the agenda, statement by the ICRC, New York, 17 October 2014, available at: www.icrc.org/en/ document/promotion-and-protection-rights-children-icrc-statement-united-nations-2014\#.VHeHqBzP87k; UN HRC, 25th regular session, statement by the ICRC, Geneva, 25 March 2014, available at: www.icrc.org/ eng/resources/documents/statement/2014/03-25-human-rights-council-combating-sexual-violence-drc.htm.

174 See Council of Delegates, Report on the Workshop "Movement Response to Sexual and Gender-Based Violence in Armed Conflict and Disaster", 2013, available at: www.icrc.org/eng/assets/files/red-crosscrescent-movement/council-delegates-2013/cod13-ws9-sgbv-final-report-eng.pdf.

175 S/RES/1820 (2008), op. para. 1; S/RES/1888 (2009), op. para. 1; S/RES/1960 (2010), op. para. 1; S/RES/ 2106 (2013), op. para. 11

176 S/RES/1807 (2008), para. 13(e).

177 For the UN, transitional justice means: "the full range of processes and mechanisms associated with a society's attempt to come to terms with a legacy of large-scale past abuses, in order to ensure accountability, serve justice and achieve reconciliation. Transitional justice consists of both judicial and non-judicial processes and mechanisms, including prosecution initiatives, truth-seeking, reparations programmes, institutional reform or an appropriate combination thereof. Furthermore, comprehensive national consultations, particularly with those affected by human rights violations, have been recognized as [a] critical element of transitional justice." See UN Doc. A/HRC/27/21, 30 June 2014, para. 6.

178 UN Doc. A/HRC/27/21, 30 June 2014. 
of IHL compliance mechanisms to identify, prevent and halt IHL violations (including sexual violence) and the need to develop new ones is a much wider issue that is the subject of an ongoing debate among States in the context of the Swiss-ICRC initiative on Strengthening Legal Protection for Victims of Armed Conflicts ("compliance track"). ${ }^{179}$

Regarding prosecutions, international criminal law has made immense progress in the last two decades. However, international prosecutions of sexual violence remain rare in practice (compared to the occurrence of these crimes in the contexts that have been addressed by the ad hoc tribunals and by the ICC). In the context of the Lubanga case, for instance, criticisms were expressed because the ICC prosecutor did not bring charges related to sexual violence despite evidence that came out in court pointing to widespread sexual violence against child soldiers; and because the judges did not re-characterize the evidence of sexual violence under the existing charges of war crimes, notably the crime of enlistment, conscription of children or use of children in hostilities. ${ }^{180}$ There were, however, both substantial and procedural impediments. On the substantial side, the prosecutor held that amending the indictment during the presentation of the prosecution case would have been contrary to the due process rights of the accused. On the procedural side, the ICC Appeals Chamber considered that it was not permissible for the judges to change the legal characterization of the facts to include crimes associated with sexual violence. ${ }^{181}$

One of the possible reasons why sexual violence is rarely prosecuted is its frequent invisibility and the inherent difficulty in the collection of evidence necessary to prove that sexual crimes have been committed, as well as in the identification of perpetrators. Another possible reason might be the fact that international courts and tribunals often prosecute high-ranking officials and that, in practice, it may be particularly difficult to prove their responsibility for the perpetration of sexual crimes by their subordinates, especially if orders were not given to that effect and if sexual crimes were simply tolerated. In the context of its PSVI initiative, the United Kingdom has thus drafted - after having consulted a range of experts in the field - an International Protocol on the Documentation and Investigation of Sexual Violence in Armed Conflicts, and launched it in

179 For further information, see www.icrc.org/eng/what-we-do/other-activities/development-ihl/strengtheninglegal-protection-compliance.htm.

180 See Dissenting Opinion of Juge Odio Benito in ICC, Prosecutor v. Lubanga, Case No. ICC-01/04-01/06, Judgment (Trial Chamber), 14 March 2012. See also International Federation for Human Rights (FIDH), Crimes of Sexual Violence and the Lubanga Case: Interview with Patricia Viseur Sellers, 12 March 2012, available at: www.fidh.org/International-Federation-for-Human-Rights/Africa/democraticrepublic-of-congo/DRC-ICC/Crimes-of-sexual-violence-and-the. See also Dov Jacobs, "Lubanga Decision Roundtable: Lubanga, Sexual Violence and the Legal Re-Characterization of Facts", Opinio Juris, 18 March 2012, available at: http://opiniojuris.org/2012/03/18/lubanga-decision-roundtable-lubanga-sexual-violenceand-the-legal-re-characterization-of-facts/; Lisa Gambone, "Failure to Charge: The ICC, Lubanga and Sexual Violence Crimes in the DRC", Foreign Policy Association, 22 July 2009, available at: http:// foreignpolicyblogs.com/2009/07/22/failure-to-charge-the-icc-lubanga-sexual-violence-crimes-in-the-drc/.

181 See ICC, Prosecutor v. Lubanga, Case No ICC-01/04-01/06, Judgment (Trial Chamber), 14 March 2012, paras 629-630. See also the discussions of the commentators in the previous footnote. 
$2014 .{ }^{182}$ The purpose of this non-binding protocol is to put an end to the impunity of perpetrators of sexual violence in conflict situations by helping national and international practitioners to investigate and document sexual violence worldwide. It provides guidelines on the documentation of sexual violence in practice and tackles issues such as documentation/investigation planning, identification of survivors and witnesses, testimonies, interviewing, and storing of information.

The international community has been very active in recent years in its efforts to combat sexual violence in various and complementary ways. It is to be hoped that these efforts will bear fruit.

\section{Conclusion}

Rape and other forms of sexual violence are absolutely prohibited under both IHL and international human rights law. The Geneva Conventions and their Additional Protocols prohibit expressly rape. They also outlaw cruel or inhuman treatment and torture, outrages upon personal dignity, indecent assault and enforced prostitution, and require respect for persons and honour. The IHL prohibition of rape and other forms of sexual violence applies to both international and non-international armed conflicts and is also part of customary law. Human rights law prohibits sexual violence at all times. This is done first and foremost through the prohibition of torture or cruel, inhuman or degrading treatment or punishment. Other human rights are also relevant, such as the prohibition of sexual slavery, trafficking of persons for the purpose of prostitution of others or other forms of sexual exploitation, the right to privacy or to a private life, and the prohibition of discrimination. Rape and other forms of sexual violence can amount to international crimes - war crimes, crimes against humanity and acts of genocide when the conditions for such crimes (including the contextual elements) are fulfilled. As such, they entail individual criminal responsibility.

The international legal framework for the prohibition and criminalization of sexual violence is thus extremely strong, even if imperfect. Sexual violence is one of those areas where the different international law branches (IHL, human rights law, international criminal law) echo and reinforce each other, providing for an essential complementarity.

Despite these legal achievements, the reality on the ground is appalling. In order to fill the gap between the law and the reality, there is an urgent need to strengthen the implementation of the international prohibition of sexual violence and the prosecution of sexual violence both at the domestic and international levels. At the domestic level, proper implementation of the prohibition of sexual violence goes beyond a mere translation of international law and into domestic rules. Large institutional reforms are needed sometimes to ensure respect for the 
law. At the international level, effective IHL compliance mechanisms are needed and further efforts must be made to ensure that sexual crimes are properly investigated and prosecuted by international judicial bodies.

Eliminating sexual violence in armed conflicts is an ambitious - some would say utopic - project. States and humanitarian actors must not capitulate, however, as sexual violence is neither an inevitable nor an inherent component of armed conflicts. 